\title{
NO OUTSOURCING OF LAW? W TO LAW AS PRACTICED BY WTO COURTS
}

\author{
By Petros C. Mavroidis*
}

This article provides a critical assessment of the corpus of law that the adjudicating bodies of the World Trade Organization (WTO) — the Appellate Body (AB) and panels ${ }^{1}$ — have used since the organization was established on January $1,1995 .{ }^{2}$ After presenting a taxonomy of WTO law, I move to discern, and to provide a critical assessment of, the philosophy of the WTO adjudicating bodies, when called to interpret it. In discussing the law that WTO adjudicating bodies have used, I distinguish between sources of WTO law and interpretative elements. This distinction will be explicated in part I below. Part II provides a taxonomy of the sources of WTO law, and part III a taxonomy of the interpretative elements used to illuminate those sources. Part IV concludes.

\section{TERMinOlOgY}

The term sources of law refers to the law governing relations among parties in an adjudicative setting. The parties themselves have the power to identify the law that an adjudicator whom they appoint will apply to their relationship. With the exception of jus cogens, from which no deviation is allowed-states have complete contractual autonomy to determine the law that will regulate their relations.

The WTO is an organization based upon an international contract among sovereign states and customs territories. ${ }^{3}$ WTO members are bound in their behavior not only by WTO law, but also by a panoply of other customary and conventional international law, which is not necessarily symmetric for all of them. The focus of this article is not the law that governs their behavior in international relations in general, but rather the law that they are obligated to observe by virtue of their WTO membership_-which is how the term sources of law is understood here. Through the regulatory framework embedded in the WTO Dispute Settlement Understanding (DSU), the WTO members (principals) have provided WTO "courts"4

* Edwin B. Parker Professor of Law at Columbia Law School, Professor of Law at the University of Neuchâtel, and Research Fellow at the Centre for Economic Policy Research. I would like to thank Pauline Lièvre for endless discussions on this issue, and Eyal Benvenisti for excellent comments on a previous draft. This article is for David Palmeter.

${ }^{1}$ The Dispute Settlement Body (DSB) is not an adjudicating body since it can only adopt or reject (as presented) the findings of panels or the Appellate Body (AB).

2 The cutoff date is July 31, 2007.

3 The term "contract" has no special connotation in this article. It is used as equivalent to "agreement," "contractual arrangement," or similar expressions.

${ }^{4}$ There are two such bodies, as briefly alluded to above: panels, which are the 'court' of first instance, and the AB, which hears appeals against panel reports. To be sure, the term "courts" is not used in the W TO agreements. Panels and the $\mathrm{AB}$ are usually referred to in literature as quasi-judicial bodies since adjudication in the WTO contains 
(agents) with the authority to interpret those sources of law. And agents must, in turn, perform their tasks without undoing the balance of rights and obligations as struck by the principals. ${ }^{5}$

The sources of WTO law are the covered agreements that appear in Appendix 1 of the DSU. ${ }^{6}$ These agreements include, through incorporation, provisions of various other international agreements, which should also be regarded as sources of WTO law. ${ }^{7}$

The covered and incorporated agreements, as described above, do not exhaust the WTO sources of law. There are additional sources of WTO law-namely, (1) state practice, (2) secondary law, and (3) the exercise of implied powers by WTO adjudicating bodies.

elements of diplomacy: bilateral consultations must precede the referral of a dispute to a panel. Once a dispute has been referred to a panel, however, the procedure is quintessentially judicial.

${ }^{5}$ Article 3.2 of the WTO Dispute Settlement Understanding provides that the dispute settlement system "cannot add to or diminish the rights and obligations provided in the covered agreements." See Understanding on Rules and Procedures Governing the Settlement of Disputes [hereinafter DSU], Apr. 15, 1994, Marrakesh Agreement Establishing the World Trade Organization [hereinafter W TO Agreement], Annex 2, in WORLD TRADE ORGANIZATION, THE RESULTS OF THE URUGUAY ROUND OF MULTILATERAL TRADE NEGOTIATIONS: THE LEGAL TEXTS 354 (1999) [hereinafter THE LEGAL TEXTS], 1869 UNTS 401, 33 ILM 1226 (1994). The scope of the powers entrusted on WTO courts is thus clearly delimited: the WTO members did not entrust them with powers beyond clarifying (interpreting) the covered agreements. W TO legal texts are available at $<$ http://www.wto.org/ english/docs_e/legal_e/legal_e.htm>.

${ }^{6}$ The General Agreement on Tariffs and Trade, Oct. 30, 1947, TIAS No. 1700, 55 UNTS 194 [hereinafter GATT] (regulating trade in goods), the General Agreement on Trade in Services, Apr. 15, 1994, W TO Agreement, supra note 5, Annex 1B, in THE LEGAL TEXTS, supra note 5, at 284 (1999), 1869 UNTS 183, reprinted in 33 ILM 1167 (1994) [hereinafter GATS] (trade in services), the Agreement on Trade-Related Aspects of Intellectual Property Rights, Apr. 15, 1994, W TO Agreement, Annex 1C, in THE LEGAL TEXTS, supra note 5, at 320 (1999), 1869 UNTS 299, reprinted in 33 ILM 1197 (1994) [hereinafter TRIPS Agreement] (regulating trade related intellectual property rights), and the DSU: these four agreements bind all W TO members. To those, the framers added the four plurilateral agreements that were in force on January 1, 1995, and that bind a subset of the W TO membership only (those that accepted to adhere to these arrangements). The W TO AB has, from early on, construed all of the multilateral covered agreements as one agreement, that is, the WTO Agreement and its annexes.

7 The International Court of Justice (ICJ) is also limited in the cases that it may hear and may also be limited in the law that it can apply. Article 38(1) of the ICJ Statute, although it is taken as a statement of the sources of public international law, serves to define, in effect, the law applicable by the ICJ, at least insofar as the compromis providing the ICJ with authority in any particular adjudication does not specify a more limited universe of law. The article provides as follows:

1. The Court, whose function is to decide in accordance with international law such disputes as are submitted to it, shall apply:

a. international conventions, whether general or particular, establishing rules expressly recognized by the contesting states;

b. international custom, as evidence of a general practice accepted as law;

c. the general principles of law recognized by civilized nations;

d. subject to the provisions of Article 59, judicial decisions and the teachings of the most highly qualified publicists of the various nations, as subsidiary means for the determination of rules of law.

2. This provision shall not prejudice the power of the Court to decide a case ex aequo et bono, if the parties agree thereto.

Some voices in the literature suggest that the ICJ's legislative will can still be further fine-tuned. Higgins, for example, has taken the view that there are two sources of public international law: treaty and custom. ROSALYN HIGGINS, PROBLEMS AND PROCESS: INTERNATIONAL LAW AND HOW WE USE IT (1994). She distances herself from the position that general principles of law are a source of law, arguing that a general principle of law serves the purpose of interpreting other sources of law rather than creating autonomous rights and obligations. This assertion is true for most principles, but there are some borderline cases. For example, estoppel, see infra notes $91-96$ and accompanying text, is a general principle of law accepted as such across international jurisdictions. It is not, however, an interpretative source of law; rather, it conditions the right to exercise what would otherwise be one's legal rights. 
None of these terms is self-interpreting, so illustrations are appropriate here. With respect to state practice, a plausible case can be made that Article XXIX of the General Agreement on Tariffs and Trade ${ }^{8}$ (GATT) has fallen into desuetude as a result of state practice. This provision requires WTO members to observe certain chapters of the Havana Charter, ${ }^{9}$ pending the acceptance of the latter and the establishment of the International Trade Organization (ITO). The ITO never came into being, and it seems certain that it will not: the advent of the WTO on January 1, 1995, signaled the definitive end to the ITO saga. In the 1960s and 1970s, many of the countries that had acceded to the GATT had no domestic competition law and were engaging, as is widely reported in the literature, in restrictive business practices, thus violating the letter and the spirit of Chapter V of the Havana Charter, one of the chapters that they were supposedly expected to observe by virtue of GATT Article XXIX. Since no complaint has ever been filed alleging a violation of Article XXIX, the available evidence suggests that in WTO state practice, the provision is legally inoperative. ${ }^{10}$ State practice can thus relegate a source of law into desuetude. ${ }^{11}$

With respect to secondary law, the covered agreements themselves establish a series of WTO organs and provide them with the legal capacity to create law. Article IX of the WTO Agreement, ${ }^{12}$ for example, states that the WTO members can, through joint action, adopt interpretations of the existing legal framework, and Article X provides that members can, through joint action, adopt amendments of the W TO Agreement. Indeed, the road to adopting the first ever WTO amendment has been opened, following a decision by the WTO General Council to amend Article 31 of the Agreement on Trade-Related Aspects of Intellectual Property Rights, as I discuss below. The WTO Agreement thus provides for something akin to secondary law. ${ }^{13}$ The power to adopt interpretations or amendments is conferred, by virtue of these provisions, to the highest organs established, the WTO Ministerial Council and General Council.

Under this category of secondary law, the work of the various lower in hierarchy WTO bodies, the so-called committees, such as the Antidumping Committee, which meet and often adopt decisions and recommendations that could be of general applicability, raises the question whether they themselves have the power to create law. ${ }^{14}$ Their decisions and recommendations are not necessarily normative in character in that they do not necessarily purport to regulate any

\footnotetext{
${ }^{8}$ Supra note 6.

${ }^{9}$ Havana Charter for an International Trade Organization, UN Doc. E/CONF.2/78 (Mar. 24, 1948).

${ }^{10}$ Although a WTO panel has drawn on this provision, see infra note 32 and accompanying text, no panel has recognized it as source of specific rights and obligations.

${ }^{11}$ To my knowledge, no right has ever been added to the sources of WTO law as a result of state practice. The panel on Mexico-Telecoms, see infra note 32 and accompanying text, used Article XXIX of the GATT to confirm a meaning that it had reached. It did not point to any state practice whereby a state was behaving in conformity with this provision because it felt compelled to do so.

12 Supra note 5.

${ }^{13}$ W TO adjudicating bodies have never used this term, although, as we will see, they have made references to acts that could fall within its purview.

${ }^{14}$ Wolfgang Benedek appears to have been the first to use the term secondary law to describe a series of consensusbased decisions by the GATT contracting parties, see WOLFGANG BENEDEK, DAS GATT AUS VÖLKERRECHTLICHER SICHT (1990). In the GATT, references to the "CONTRACTING PARTIES" (all in capitals) refers to the highest organ; the GATT “CONTRACTING PARTIES” decide, through joint action, all issues coming under the purview of the GATT. See GATT, supra note 6, Art. XXV.
} 
particular transactions. But sometimes they do, so the question is: what is the difference, if any, between their output and that of higher WTO bodies when those convene, for example, under the auspices of Article IX of the WTO Agreement? What criterion should be used to distinguish between acts that could qualify as sources of law and that thereby establish standards to be applied in other cases, and acts that should not be so considered?

As we will see in more detail in part II, a plausible case can be made in favor of the position that legislative intent emerges as the criterion that has come to be privileged in WTO case law: assuming that the framers have entrusted an organ — whether a committee, the $A B$, or a panelwith the legal authority to adopt a particular act that is normative in character, and if the organ at hand has acted within the predefined parameters of discretion, its act should be accepted as a source of law. For example, WTO members gave the AB the authority to establish its own working procedures (DSU Article 17.9). The lawmaking power of the AB is consequently a reflection of the primary law, since the legislative intent of the framers is, in this respect, unambiguous. $^{15}$

In other situations the framers have not explicitly provided an organ with the power to regulate specific issues, but unless implied powers are recognized, the organ in question cannot fulfill its function. The DSU does not explicitly regulate how to allocate the burden of proof, but panels and the $\mathrm{AB}$ needed to address that issue early in their history. ${ }^{16}$ In U.S.-Wool Shirts and Blouses, ${ }^{17}$ the $\mathrm{AB}$ allocated the burden of proof by referring to general principles of law; unless we recognize that WTO adjudicating bodies possess implied powers to allocate the burden of proof - precisely because of the incompleteness of the DSU in this respect-they will find it impossible to perform their task. These implied powers arguably stem from DSU Article 11, which imposes a duty to make an "objective assessment" but does not itself explicitly refer to issues such as allocating the burden of proof. ${ }^{18}$

It would be incorrect to infer, however, that any gap-filling exercise is a source of law. ${ }^{19}$ The AB's findings in U.S. - Wool Shirts and Blouses concerning burden of proof were intended to be normative rather than case-specific: the allocation of burden of proof should not change based on the identity of the parties. More generally, implied powers should be limited to certain procedural rights and obligations and should not be extended to substantive rights. Otherwise, the judge would risk undoing the balance of rights and obligations as agreed by the framers. ${ }^{20}$

Renegotiation - for example, through amendments, state practice, or the exercise of implied powers - is another source of WTO law and, by the same token, another way to complete the

15 The AB has used this authority; the latest version of the Working Procedures for Appellate Review, WTO Doc. $\mathrm{WT} / \mathrm{AB} / \mathrm{WP} / 5$, available at $<$ http://www.wto.org/english/tratop_e/dispu_e/ab_e.htm $>$, was published in January 2005.

${ }^{16}$ Lorand Bartels, Applicable Law in WTO Dispute Settlement Proceedings, 35 J. WORLD TRADE 499 (2001), was the first to make this point.

${ }_{17}$ Appellate Body Report, United States_-Measure Affecting Imports of Woven Wool Shirts and Blouses from India, WT/DS33/AB/R \& corr.1 (adopted May 23, 1997).

${ }^{18}$ Gabrielle Marceau, WTO Dispute Settlement and Human Rights, 13 EUR. J. INT'L L. 753 (2002), makes a series of arguments in favor of this approach.

${ }^{19}$ A panel might, for example, decide to have an extra internal meeting in light of disagreements among its members on a particular issue.

${ }^{20}$ The judge should not exceed the boundaries established by DSU Article 11; that is, it should use its implied powers to ensure that its assessment is objective. It is true, however, that the boundaries are unclear. 
WTO contract. ${ }^{21}$ Whereas an amendment or state practice (provided it is unanimous) complete the original contract by adding new obligations (or subtracting from them), the exercise of implied powers aims to fill the gaps — that is, to apply general language (such as "objective assessment") from WTO agreements to specific contexts (for example, to allocate the burden of proof). Implied powers cannot be used to undo the balance of rights and obligations, for WTO organs, which exercise those powers, do not have the power to do that (as is also the case with WTO “courts," as per DSU Article 3.2).

The sources of WTO law are often not self-explanatory. WTO adjudicating bodies, which are requested to interpret them, often need to rely on various interpretative elements in reaching their conclusions. Whereas defining the sources of law was the privilege of the WTO's framers, identifying those interpretative elements is the privilege of the adjudicating bodies. Once again, when adding such elements, the agents cannot undo the balance of rights and obligations as struck by the framers. ${ }^{22}$

Recall that this point is captured by the imperative embedded in DSU Article 3.2: "Recommendations and rulings of the DSB cannot add to or diminish the rights and obligations provided in the covered agreements." ${ }^{23}$ In order to ensure that these recommendations and rulings will not exceed these bounds, DSU Article 3.2 also specifies the interpretative method that adjudicating bodies must use: they must reach their interpretations using customary rules of interpretation. WTO adjudicating bodies have understood this provision to be an implicit reference to the relevant provisions of the Vienna Convention on the Law of Treaties (VCLT). ${ }^{24}$ That treaty authorizes the use of extra-contractual (extra-WTO in our case) interpretative elements in order to interpret an international contract. Trachtman emphasizes the distinction between interpretation and application of law: if, for example, the WTO AB were to use a multilateral environmental agreement (MEA) to make the point that sea turtles are an exhaustible natural resource, it should not, according to this distinction, be applying the MEA provision in a dispute between two WTO members; it should be simply interpreting Article XX (g) of the GATT, using the MEA as an interpretative element of a term that features in that provision. This approach is very much in line with the one advocated in the DSU (Article 3.2) and in this

\footnotetext{
${ }^{21}$ Contracts may be incomplete for various reasons. It is difficult, for example, to foresee all future contingencies, and negotiators might feel that the contract will be best completed through renegotiation or adjudication. In particular, negotiators might feel that they have reached the point of diminishing returns in the negotiations, so that too much work will be required to achieve marginally better outcomes. At that point they will stop negotiating and leave it to subsequent negotiation or adjudication to fill the gaps. For a formal explanation, see Pierpaolo Battigalli \& Giovanni Maggi, Rigidity, Discretion, and the Costs of Writing Contracts, 92 AM. ECON. REV. 798 (2002); see also RiCHARD A. POSNER, OVERCOMING LAW (1995). For an application in the WTO context, see Joel P. Trachtman, The Domain of WTO Dispute Resolution, 40 HARV. INT'L L.J. 333 (1999).

${ }^{22}$ This point is not just a matter of semantics. When WTO members felt that WTO adjudicating bodies undid the balance of rights and obligations that they had negotiated, they reacted strongly. See Petros C. Mavroidis, Amicus Curiae Briefs Before the WTO: Much Ado About Nothing, in EUROPEAN INTEGRATION AND INTERNATIONAL CO-ORDINATION: STUDIES IN TRANSNATIONAL ECONOMIC LAW IN HONOUR OF CLAUS-DIETER EHLERMANN 317 (Armin von Bogdandy, Petros C. Mavroidis, \& Yves Mény eds., 2004). Mavroidis reports on the WTO General Council's special session that was dedicated to a discussion of whether to allow for amici to participate in WTO proceedings. During that session the majority of WTO members expressed the view that the AB was acting ultra vires in allowing amici to participate.

${ }^{23}$ The DSB, see supra note 2, will not alter the findings of the panel or AB. It will decide to adopt or reject the findings of a panel/AB report submitted to it as such — that is, without being in a position to modify its findings.

${ }^{24}$ May 23, 1969, 1155 UNTS 331.
} 


\begin{tabular}{ll}
\hline \multicolumn{1}{c}{ Sources of law } & \\
\hline Covered agreements & DSU Appendix 1 \\
Incorporated international agreements & Havana Charter \\
& Agreements referred to in \\
& TRIPS Agreement \\
& SCM Agreement \\
Secondary law & Authoritative interpretations \\
& Amendments \\
& Waivers \\
& Decisions \\
& Recommendations \\
Implied powers & International agreements to which WTO is a party \\
& Allocation of burden of proof \\
Interpretative elements & Amici participation \\
Oxford English Dictionary & Extended third-party rights \\
Travaux préparatoires of the W TO Agreement & \\
Practice/agreements subsequent to WTO & \\
Agreement & \\
GATT panel reports & \\
WTO panel and AB reports & \\
International agreements not incorporated into & \\
the W TO Agreement & \\
Acts adopted by various international & \\
organizations & \\
Decisions by international courts & \\
Domestic law and practice & \\
Unilateral declarations by W TO members & \\
Customary international law & \\
General principles of law & \\
Doctrine & \\
\hline
\end{tabular}

article. ${ }^{25}$ Through the interpretation of the WTO Agreement, WTO adjudicating bodies have identified a plethora of interpretative elements. The text box lists the various sources of law and their interpretative elements as they have emerged in WTO case law.

Finally, it is worth underscoring the separation between the law applicable in WTO adjudication and the law applicable, more broadly, to behavior. For example, although jus cogens does not figure in Appendix 1, all WTO members are bound by it, and specific provisions of covered agreements implicitly import it. To illustrate the point, GATT Article III requires that, with respect to domestic regulation affecting trade, WTO members must not discriminate across domestic and imported like products, but a WTO member that imposes a sales embargo on racist papers (assuming racist and nonracist papers are considered to be like products, resulting in a violation of GATT Article III) might, if challenged, invoke jus cogens under GATT Article XX.

25 See Trachtman, supra note 21; Joel P. Trachtman, Book Review, 98 AJIL 855 (2002) (reviewing JOOST PAUWELYN, CONFLICT OF NORMS IN PUBLIC INTERNATIONAL LAW: HOW WTO LAW RELATES TO OTHER RULES OF INTERNATIONAL LAW (2003)). 


\section{SOURCES OF LAW APPLICABLE IN WTO AdJUDICATION}

\section{The Covered Agreements}

Appendix 1 to the DSU includes an exhaustive list of all covered agreements.

\section{International Agreements Incorporated in the Covered Agreements}

The texts of several WTO agreements explicitly refer to other international agreements, which are therefore sources of WTO law. ${ }^{26}$ They are presented in brief in what follows.

The Havana Charter. Portions of the Havana Charter were incorporated into the GATT through GATT Article XXIX, but this provision appears to have fallen into desuetude.

Agreements mentioned in the TRIPS Agreement. The agreements mentioned in the Agreement on Trade-Related Aspects of Intellectual Property Rights ${ }^{27}$ (specifically, Article 1.3) include major international intellectual property conventions, the Paris Convention (1967), the Berne Convention (1971), the Rome Convention, and the Treaty on Intellectual Property in Respect of Integrated Circuits; for example, Article 9 of the TRIPS Agreement requires WTO members to comply with Articles 1-21 of the Berne Convention.

Agreements mentioned in the SCM Agreement. The WTO Agreement on Subsidies and Countervailing Measures ${ }^{28}$ provides that government grants of export credits in conformity with the provisions of the Arrangement on Guidelines for Officially Supported Export Credits $^{29}$ (Arrangement on Guidelines) of the Organisation for Economic Co-operation and Development (OECD) shall not be considered export subsidies. Annex I $(\mathrm{k})$ of the SCM Agreement states:

[I] $\mathrm{f}$ a Member is a party to an international undertaking on official export credits to which at least twelve original Members to this Agreement are parties as of 1 January 1979 (or a successor undertaking which has been adopted by those original Members), or if in practice a Member applies the interest rates provisions of the relevant undertaking, an export credit practice which is in conformity with those provisions shall not be considered an export subsidy prohibited by this Agreement.

The "international undertaking" described is the OECD Arrangement on Guidelines; by virtue of its incorporation, it is, of course, a source of WTO law. ${ }^{30}$

Other international agreements. GATT Article XV:6 refers to the obligation of WTO members either to become members of the International Monetary Fund (IMF), or to enter into a special exchange agreement with the GATT contracting parties. In general, this provision recognizes a special consultative role for the IMF in case a WTO member wishes to justify its restrictions on grounds coming under the fund's competence. This discipline has largely been overtaken by the agreement between the WTO and the IMF discussed below.

${ }^{26}$ The agreements discussed here are not covered agreements, as they do not appear in Appendix 1 to the DSU.

${ }^{27}$ See supra note 6.

${ }^{28}$ See supra note 6.

${ }^{29}$ The arrangement, at $<$ http://www.imf.org/external/pubs/ft/eds/Eng/Guide/index.htm $>$, was concluded in 1978 and last revised in 1998.

${ }^{30}$ The wording of this provision makes it plain that the OECD arrangement applies to the relationship across WTO members. 
GATT Article XXI and General Agreement on Trade in Services (GATS) Article XIV bis reflect the boundaries of the obligations assumed under GATT and GATS, respectively, and clarify that those obligations are trumped by the obligations that WTO members have assumed, by virtue of the UN Charter, to safeguard peace and international security. ${ }^{31}$

The legal relevance of the agreements mentioned in the WTO Agreement. The panel report in on Mexico-Telecoms ${ }^{32}$ used Article 46 of the Havana Charter to inform its understanding of the term "anti-competitive practice." In so doing that, the panel made it clear that it was using the relevant provision of the Havana Charter as a supplementary means of interpretation and not as a source of law applicable in adjudication.

As far as the remaining agreements mentioned in the WTO Agreement are concerned, it is clear that they apply in the relationships across WTO members. It is less clear whether amendments to those agreements, which take place outside WTO confines, bind WTO members. The panel report in U.S.-Section 110(5) Copyright Act ${ }^{33}$ made clear that WTO members have to observe the incorporated provisions of the Berne Convention: "[T]he substantive rules of the Berne Convention (1971), including the provisions of its Articles 11bis(1)(iii) and 11(1)(ii), have become part of the TRIPS Agreement and as provisions of that Agreement have to be read as applying to WTO Members." Because they have been incorporated into the TRIPS Agreement, such provisions cannot be modified or amended in a way that has effect within the WTO system of adjudication, absent a modification or amendment of the TRIPS Agreement itself.

The panel report in U.S.-Section 110(5) Copyright Act discusses the legal relevance of a report adopted in connection with, and subsequent to, the conclusion of the 1971 Berne Convention, which, as noted immediately above, is of direct relevance to the interpretation of the TRIPS Agreement. In that case, the panel was asked to interpret the term minor exceptions appearing in Articles 11(1) and 11 bis (1) of the Berne Convention. The panel noted that parties to the Convention had requested that their general rapporteur review the issue. Though not inserted as an amendment to the Convention, the rapporteur's report was adopted by the contracting parties. The adoption predated the entry into force of the WTO Agreement. The adoption in itself sufficed for the WTO panel to consider the report as a subsequent agreement between the parties (to the Berne Convention and not the WTO Agreement) in accordance with VCLT Article 31(2)(a).

Item (k) of Annex I of the WTO's SCM Agreement refers to "an international undertaking on official export credits to which at least twelve original Members to this Agreement are parties as of 1 January 1979 (or a successor undertaking which has been adopted by those original Members)" (emphasis added): the lack of explicit reference notwithstanding, it has been understood that the reference in item $(\mathrm{k})$ is to the OECD Arrangement on Guidelines. During the proceedings that led to the panel report in Brazil-Aircraft (Article 21.5-Second Recourse), ${ }^{34}$ the

${ }^{31}$ On this issue see DAVID LUFF, LE DROIT DE L'ORGANISATION MONDIALE DU COMMERCE: ANALYSE CRITIQUE (2004).

${ }^{32}$ Panel Report, Mexico-Measures Affecting Telecommunications Services, para. 7.236, WT/DS204/R (adopted June 1, 2004) [hereinafter Mexico-Telecoms]. The panel did not request that the defendant behave in a manner compatible with the Havana Charter; its findings were based on the GATS.

${ }_{33}$ Panel Report, United States_Section 110(5) of the U.S. Copyright Act, para. 6.18, WT/DS160/R (adopted July 27, 2000) (emphasis added).

${ }^{34}$ Panel Report, Brazil-Export Financing Programme for Aircraft (Second Recourse by Canada to Article 21.5 of the DSU), paras. 5.80-.91, W T/DS46/RW/2 (adopted Aug. 23, 2001). 
panel faced, inter alia, the following question: to what extent is the relevant text of the OECD arrangement that of 1992, which is referred to in the SCM Agreement, or that of the 1998, which was negotiated only among OECD members - that is, among only a small minority of WTO members? The panel decided that, because of the reference in item (k) to the successor undertaking, it also had to take into account the 1998 arrangement. ${ }^{35}$

Even the preparatory work of the incorporated agreements has been of legal relevance in WTO proceedings: the panel, in its report in Canada-Pharmaceutical Patents, ${ }^{36}$ took into account the preparatory work of the Berne Convention to clarify the meaning of a condition included in a TRIPS provision that it was called on to interpret. In justifying its choice, the panel noted that the text of the condition in question was clearly drawn from the Berne Convention.

\section{Secondary Law}

As already stated above, the WTO Agreement provides for the possibility that the WTO organs create law. I propose the following classification:

— joint action ${ }^{37}$ by the WTO membership (interpretations, waivers, amendments)

— decisions and recommendations adopted by WTO organs

— international agreements signed by the WTO

The WTO Agreement provides for the possibility of secondary law but does not specify its legal value. WTO adjudicating bodies have pronounced on the legal significance of secondary law: while nominally refusing to accept the lawmaking powers of WTO organs or even to use the term secondary law, those adjudicating organs have de facto shown substantial deference toward actions taken collectively by the WTO members, even when such actions were taken at the lowest level of institutional integration, that of WTO committees.

Joint action. Although this option has never been used, the WTO membership can, by virtue of Article IX:2 of the WTO Agreement, adopt interpretations of that Agreement-primary law-by a three-fourths majority, assuming no consensus has been reached. Although the WTO Agreement does not specifically address the issue of the legal value of such interpretations, there is reason to believe that they are binding on WTO members and on WTO adjudicating bodies. Indeed, as will be shown below, WTO adjudicating bodies have not questioned the legality of waivers, which are adopted following the same voting procedures as for interpretations (three-fourths of members) ${ }^{38}$ this practice suggests that interpretations will likewise be accepted.

35 The panel cannot be accused of overstepping its mandate. It is, however, remarkable that the WTO membership agreed in 1994 that a subset of the WTO membership (the OECD members) had the legal right to modify not only their inter se legal relations, but the rights and obligations of the totality of the WTO membership.

${ }^{36}$ Panel Report, Canada_Patent Protection of Pharmaceutical Products, para. 7.70, WT/DS114/R (adopted Apr. 7, 2000) [hereinafter Canada-Pharmaceutical Patents].

37 This term, which is from the GATT (ArticleXXV), refers to the decision making by GATT contracting parties. The term is not formally used in the WTO Agreement; I use it to capture three acts by WTO members acting jointly: interpretations, amendments, and waivers.

${ }^{38}$ In fact, in contrast to the process for seeking interpretations, the process for waivers does not require that one first look for a consensus. Practice reveals that when three-fourths of the members have cast a favorable vote, a waiver has been adopted. An interpretation, as a matter of legislative preference, should enjoy a higher degree of legitimacy for two reasons: by virtue of the higher value attached to the search for consensus, and also because an interpretation is good law for all WTO members, whereas a waiver is merely a temporary license to disobey the W TO Agreement. 
Similar conclusions can be drawn with respect to amendments under Article X of the WTO Agreement - which amend the covered agreements and are therefore subject to W TO dispute settlement as parts of those agreements. The provisions of the covered agreements mentioned in Article X:2 of the WTO Agreement can be amended by consensus or, in the absence of consensus, by various majority rules, depending upon the particular provision in question. On December 6, 2005, the WTO General Council opened the way for the adoption of the first (and, so far, only) amendment of the WTO Agreement by consensus. ${ }^{39}$

Decisions and recommendations by WTO organs. The WTO Agreement does not provide an exhaustive list of all its organs: Article IV, which reflects the structure of the WTO, does not explicitly refer to panels, the $\mathrm{AB},{ }^{40}$ or committees, such as the Antidumping Committee. In principle, all of the above should qualify as WTO organs since the possibility of establishing subsidiary bodies is explicitly acknowledged in various parts of this provision (Article IV:3,6), and they are explicitly mentioned in the relevant WTO agreements. The WTO Agreement does not specify when WTO organs will issue a decision and when a recommendation, and it does not even explain the difference between the two. ${ }^{41}$ These terms are nevertheless reflected in many working procedures of various WTO committees and are often used in the titles of adopted acts. We know that they are neither amendments nor interpretations, but we do not

39 The amendment reads as follows:

1. The Agreement on Trade-Related Aspects of Intellectual Property Rights (the "TRIPS Agreement") shall, upon the entry into force of the Protocol pursuant to paragraph 4, be amended as set out in the Annex to this Protocol, by inserting Article 31 bis after Article 31 and by inserting the Annex to the TRIPS Agreement after Article 73.

2. Reservations may not be entered in respect of any of the provisions of this Protocol without the consent of the other Members.

3. This Protocol shall be open for acceptance by Members until 1 December 2007 or such later date as may be decided by the Ministerial Conference.

4. This Protocol shall enter into force in accordance with paragraph 3 of Article X of the WTO Agreement.

5. This Protocol shall be deposited with the Director-General of the World Trade Organization who shall promptly furnish to each Member a certified copy thereof and a notification of each acceptance thereof pursuant to paragraph 3.

6. This Protocol shall be registered in accordance with the provisions of Article 102 of the Charter of the United Nations.

General Council Decision, Amendment of the TRIPS Agreement, WTO Doc. WT/L/641, attachment (Dec. 8, 2005). Through the new Article 31 bis, WTO members, once the amendment has been formally adopted, could outsource production of goods coming under compulsory licensing. To be sure, the amendment has not (as of this writing) been formally adopted, which would require, under Article X:3 of the WTO Agreement, a vote of twothirds of the WTO members. The period for adoption runs out on December 31, 2009, see WTO Doc. WT/L/711 (Dec. 21, 2007)). Until it has been adopted, a temporary waiver has been granted: already during the launching of the Doha Round, the Declaration on the TRIPS Agreement and Public Health, WTO Doc. WT/MIN(01)/DEC/2, para. 6 (Nov. 20, 2001), incorporated the idea that special care must be taken with respect to developing countries that cannot meet their public health objectives because of their obligations under TRIPS. The relevant provision was soon translated into operational language, and through a General Council decision adopted to this effect, WTO Doc. WT/L/540 \& Corr. 1 (Sept. 2, 2003), WTO members accepted that the obligations under TRIPS Article 31(f) should be waived for developing countries. The decision roughly reproduces the idea included in the pending amendment. The waiver is temporary, however, and its renewal uncertain; legal security will come only with formal adoption of the amendment.

${ }^{40}$ Panels and the AB clearly have no lawmaking power: they can only make recommendations to the DSB.

${ }^{41}$ There is one exception: Article IX:4 of the WTO Agreement refers to the decision to grant a waiver. 
know in what precise way they differ from these two. A look into case law offers some guidance as to their legal status.

I propose first to discuss decisions and recommendations by WTO organs (other than adjudicating bodies) and then to shift focus to the decisions by adjudicating bodies that could qualify as secondary law.

In carrying out its responsibilities, the WTO General Council-a non-adjudicative body - is not limited to acts of a general character, such as the interpretations and amendments discussed above. Its power to adopt decisions, at the request of a WTO member, is explicitly mentioned in Article IX:4 of the WTO Agreement: the WTO General Council can adopt waivers whereby it allows temporary deviations from the WTO Agreement and its annexes. ${ }^{42}$ Case law has clarified that WTO adjudicating bodies have the right, in turn, to review whether certain actions taken by WTO members are covered by a waiver or not: during the $E C$ Bananas $I I I^{43}$ litigation, both the panel and the $\mathrm{AB}$ considered the scope of the waiver granted originally by the GATT General Council, which then extended the waiver to the European Community (EC) in relation to the Lomé Convention. ${ }^{44}$ The substantive question before the panel concerned the precise requirements of the Lomé Convention. The EC and the African, Caribbean and Pacific (ACP) countries argued that the panel was not competent to answer that question. Rather, they contended that the panel should defer to the interpretation advanced by the EC and the ACP — who, as parties to the agreement, were the only legal persons competent to interpret it. ${ }^{45}$ The panel disagreed. It noted that the EC and the ACP countries initially had been granted a waiver by the GATT, allowing the preferential treatment granted by the former to the latter. That waiver was subsequently extended to the EC and ACP countries through action by the WTO General Council. In the panel's view, the waiver itself was a WTO decision that, as such, could be reviewed by a WTO panel. The AB affirmed, observing: "To determine what is 'required' [that is, the scope of the waiver] by the Lomé Convention, we must look first to the text of that Convention and identify the provisions of it that are relevant to trade in bananas, " 46 with the consequence that panels are competent to review whether actions correspond to the terms and conditions included in waivers authorizing deviations from the WTO Agreement.

Article IV:5 of the WTO Agreement mentions, in addition to the Ministerial Conference and the General Council, three other councils (GATT, GATS, TRIPS), and Article IV:6 of the WTO Agreement makes it clear that these three councils can, when required, establish subsidiary bodies that can and do adopt decisions. Other subsidiary bodies, such as the WTO Committee on Anti-dumping Practices (ADP Committee), are provided for in the relevant

\footnotetext{
${ }^{42}$ A waiver affects, of course, not only the legal situation of the addressee, but also of the rest of the WTO membership — which can no longer enforce its rights against the beneficiary, at least to the extent that such enforcement would contradict the terms of the waiver granted. Even so, and unlike interpretations or amendments, waivers do not reflect a joint will to change the current legal regime; they serve as a means of satisfying concrete requests by particular WTO members.

${ }^{43}$ Panel Report, EC-Regime for the Importation, Sale and Distribution of Bananas, WT/DS27/R (adopted Sept. 25, 1997), modified by Appellate Body Report, EC-Regime for the Importation, Sale and Distribution of Bananas, WT DS27/AB/R (adopted Sept. 25, 1997) [hereinafter EC-Bananas III].

${ }^{44}$ The Lomé Conventions were aimed at promoting the economic, social, and cultural development of the contracting parties from Africa, the Caribbean, and the Pacific. The fourth such convention, 1991 O.J. (L 229) 3, which was revised in 1995, was signed in Lomé on December 15, 1989.

${ }^{45}$ Panel Report, EC-Bananas III, supra note 43, paras. 7.95-.97.

${ }^{46}$ Appellate Body Report, EC-Bananas III, supra note 43, para. 169.
} 
agreements. These organs have decision-making powers. For example, Rule 33 of the working procedures of the ADP Committee reads: "where a decision cannot be arrived at by consensus, the matter at issue shall be referred to the Council for Trade in Goods." Not every decision by each and every WTO organ is of regulatory character. To take just one instance, even a cursory look at the working procedures of the Antidumping Committee suggests that much of its activity is not of normative character. But some of it is. For example, the period of investigation during which a domestic investigating authority must establish dumping and measure injury is nowhere defined in the Anti-dumping Agreement ${ }^{47}$ (AD Agreement). The ADP Committee has filled the gap and recommended the total length for the period of investigation (POI) that WTO members should use in determining dumping and injury. In light of the committee's wide mandate (AD Agreement Article 16), ${ }^{48}$ it would appear perfectly legitimate for the ADP Committee to adopt recommendations to this effect.

So what is the legal value of such acts? Over the years, WTO adjudicating bodies have taken a friendlier attitude toward decisions and recommendations adopted by various WTO organs (for example, committees). One of the first pronouncements to this effect came with the panel report in India-Quantitative Restrictions, ${ }^{49}$ where the panel stated that, if the committee (in the case at hand, the Committee on Balance of Payments) had already decided the issue before the panel, it could "see no reason to assume that the panel would not appropriately take those conclusions into account." Indeed, the panel indicated that, depending on the treaty language and the legal powers conferred upon an organ such as the Balance of Payments Committee, it would potentially be legally compelled to do so. Likewise, the panel report in Mexico-Antidumping Measures on Rice ${ }^{50}$ relied, in part, on the ADP Committee recommendation on the length of the POI to support its own view as to the period over which to measure injury (injury POI). Along the same lines, the panel report in EC-Pipe Fittings ${ }^{51}$ used a recommendation by the ADP Committee as a source of law to reach its conclusion that it is desirable that the period to investigate occurrences of dumping (dumping POI) substantially overlap with injury POI. Likewise, the panel in Argentina-Poultry Anti-dumping Duties ${ }^{52}$ relied on this recommendation by the ADP Committee to support its conclusion that the dumping and injury POIs should not necessarily end at the same time.

Note that the panel report in India-Quantitative Restrictions was dealing with a decision by a committee, whereas the other reports mentioned dealt with recommendations. As things

${ }^{47}$ Agreement on Implementation of Article VI of the General Agreement on Tariffs and Trade 1994, Apr. 15, 1994, WTO Agreement, supra note 5, Annex 1A, in THE LEGAL TEXTS, supra note 5, at 168 [hereinafter AD Agreement].

48 See infra notes 49-53 and accompanying text.

49 Panel Report, India-Quantitative Restrictions on Imports of Agricultural, Textile and Industrial Products, paras. 5.93-94, W T/DS90/R (adopted Sept. 22, 1999); Appellate Body Report, India-Quantitative Restrictions on Imports of Agricultural, Textile and Industrial Products, WT/DS90/AB/R (adopted Sept. 22, 1999).

${ }^{50}$ Panel Report, Mexico-Definitive Anti-dumping Measure on Rice, para. 7.62, WT/DS295/R (adopted Dec. 20, 2005), modified by Appellate Body Report, Mexico-Definitive Anti-dumping Measure on Rice, WT/DS295/ AB/R (adopted Dec. 20, 2005).

${ }^{51}$ Panel Report, EC-Anti-dumping Duties on Malleable Cast Iron Tube or Pipe Fittings from Brazil, para. 7.321, W T/DS219/R (adopted Aug. 18, 2003), modified by Appellate Body Report, EC_Anti-dumping Duties on Malleable Cast Iron Tube or Pipe Fittings from Brazil, WT/DS219/AB/R (adopted Aug. 18, 2003) [hereinafter EC-Pipe Fittings].

52 Panel Report, Argentina-Definitive Anti-dumping Duties on Poultry from Brazil, para. 7.287, W T/DS241/R (adopted May 19, 2003) [hereinafter Argentina-Poultry Anti-dumping Duties]. 
stand, especially in the field of contingent-protection instruments, where practice has been substantial, WTO adjudicating bodies seem to treat recommendations by WTO organs as supplementary means of interpretation (as when prefacing recourse to them with the such phrases as "we find support" or "our interpretation is confirmed").

Is such a classification inappropriate? It is true that a recommendation by the ADP Committee is not an interpretation: Article IX:2 of the WTO Agreement reserves the exclusive authority to adopt interpretations to two organs, the Ministerial Conference and the General Council. Article 16.1 of the AD Agreement, however, does not preclude the ADP Committee from exercising regulatory functions. Indeed, its mandate as specified in that article is quite open ended: it "shall carry out responsibilities as assigned to it under this Agreement or by the Members." In principle, nothing stops WTO members from delegating regulatory authority at this level. A recommendation like the one on the length of the POI could, for example, serve as a source of law. It dealt for the first time at the multilateral level with an issue not explicitly regulated in the $\mathrm{AD}$ Agreement; it used language that makes it clear that it was intended to serve as a guideline; and it was accepted by consensus.

A very strong counterargument can be made, however, that - in my view, at least - ultimately justifies the choice of WTO adjudicating bodies to treat such recommendations as supplementary means of interpretation and not as sources of law. The General Council has a quorum provision: Rule 16 of its working procedures specifically states that the majority of the WTO membership must be present for a quorum. ${ }^{53}$ There is no quorum requirement for any of the committees established under the various covered agreements. This difference cannot be accidental. The will of the legislator must have been to associate the General Council meetings with a certain degree of formal significance, whereas the reverse is true for committee meetings. ${ }^{54}$ By the same token, the expectation of trade delegates to the WTO must be that "serious" issues will be discussed at the General Council-level, whereas more day-to-day operations will form the subject matter of the committee mandates. Practice in the ADP, but also in other committees, amply supports this view. The recommendation concerning POIs is an exception to the items on typical agenda; normally, delegates will discuss complaints by members, implementation of panel reports, and so on. Similarly, other committees, such as the Committee on Trade and Environment, will entertain discussions on what is an environmental good or what should be the link between a multilateral environmental agreement and the WTO. The committee will stop short, however, of deciding the issue. This last step is left for higher organs, assuming a consensus has been reached.

The context of a decision or recommendation - that is, the organ adopting it-seems to be an important consideration in the W TO, which supports the view that recommendations such as the one concerning POIs were correctly treated by the panel as supplementary means and not as a source of law. This solution also has the merit of flexibility: for example, if WTO members are interesting in elevating the POI recommendation to a source of law, nothing stops them from including it in the new $\mathrm{AD}$ agreement or from adopting an interpretation to that effect. $^{55}$

${ }^{53}$ See WTO Doc. WT/L/28 (Feb. 7, 1996) (on file with author).

${ }^{54}$ There is no official data, but only anecdotal evidence, that General Council meetings attract more delegates than committee meetings do.

${ }^{55}$ Some might object, arguing that the quorum requirement is a thin reed to support a distinction with such far-reaching implications. Recall, nonetheless, that the heart of this argument concerns the expectations of WTO 
Note, finally, that one panel has even reviewed the relevance of an act by a non-standing (that is, ad hoc or nonpermanent) WTO organ, albeit as a supplementary means. In its determination that the term "anti-competitive practice" covered horizontal price fixing, the April 2004 panel report in Mexico-Telecoms ${ }^{56}$ relied, in part, on the work of the WTO Working Party on the Interaction of Trade and Competition Policies, which the panel found to be of some relevance. This working party was created by the Singapore Ministerial Conference of 1996 and had not met since September 2003, following the decision by negotiators not to renew its mandate. Although the panel issued no explicit pronouncement to this effect, the context makes obvious that the panel treated the WTO working party report as a supplementary means of interpretation; that is, the panel referred to the working party's work in order to confirm a conclusion that the panel had already reached (as per Article 32 of the VCLT). This way of proceeding is correct; nothing in the WTO Agreement or its annexes or in the working procedures of this working group can be advanced as an argument in favor of treating an intermediate result ${ }^{57}$ as a source of law.

Having concluded that the decisions and recommendation of non-adjudicative WTO organs do not quality as sources of law, we now turn to the work of adjudicative bodies.

The DSU, one of the covered agreements, explicitly acknowledges the right of WTO adjudicating bodies to establish their own working procedures. DSU Article 17.9 explicitly authorizes the $\mathrm{AB}$ to do so (which it has done). Although panels are, in principle, required to obey the working procedures in Appendix 3 to the DSU, Article 12.1 of that agreement permits them to deviate if they so choose. The primary law thus acknowledges the right of WTO adjudicating bodies (albeit not the same for all bodies) to legislate in the narrow context of their own procedures.

In addition to the power to enact procedures, WTO adjudicating bodies have on occasion created law in order to be in a position to honor their mandates - that is, to resolve the disputes before them. We took the position above that, unless one accepts that adjudicating bodies are vested with implied powers, it will sometimes be impossible for them to honor their mandate. We offered the example of allocating the burden of proof as evidence of such implied powers. But there are other examples as well: third party rights is an appropriate illustration. ${ }^{58}$ Appendix 3 does not mention extended third-party rights. When the first panel decided on extending the right of third parties so as to allow them to participate in the second substantive panel meeting, ${ }^{59}$ the panel had to establish criteria ${ }^{60}$ to which future interested parties could refer in order

members in connection with introducing an issue in a lower, not higher, organ. Lower committees sometimes meet with only a few delegates present, with the consequence that the majority of delegations learn about their decisions much later.

56 Panel Report, Mexico-Telecoms, supra note 32, para. 7.236.

${ }^{57}$ As briefly alluded to above, the Working Party on the interaction of Trade and Competition policies was not brought to a successful conclusion. Following the failure to agree in Cancun (midterm review of the Doha round), the WTO membership decided to discontinue its mandate. In the meantime, nevertheless, the working party managed to produce an impressive amount of work regarding the merits of competition policy as a complement to free trade policies.

${ }^{58}$ See DSU Art. 10. Essentially, W TO members can participate in the first panel meeting if they declare their wish to do so within the statutory deadlines.

59 Third parties do not enjoy this right. DSU App. 3, para. 6.

${ }^{60}$ Essentially, the panel would first satisfy itself that a third party had an especially strong reason for continuing to participate in a given dispute. The question of enhanced third party rights first arose in EC-Bananas III, when a number of developing-country third parties requested that they be permitted to attend all meetings between the panel and the parties to the dispute-and not simply the first meeting as per DSU Article 10.3. Panel Report, 
to enjoy the same privilege. Yet another example concerns the participation of amici curiae. Nothing in Appendix 3 provides for such participation, the conditions for which ${ }^{61}$ have been defined, instead, via the case law of the $\mathrm{AB}$ and panels. ${ }^{62}$

\section{International Agreements Signed by the WTO}

The WTO Agreement falls short of explicitly granting a treaty-making power to the WTO; the combination of various provisions nevertheless leads us to this conclusion. In particular, Article VIII:1 acknowledges that the WTO has legal personality; Article V states that the WTO General Council ${ }^{63}$ can make arrangements that will facilitate the cooperation between the WTO and institutions having a related mandate; and Article III:5 explicitly provides for cooperation between the WTO, the International Monetary Fund, and the World Bank.

The WTO has, in fact, signed international agreements. Two of them involve, as expected, the Bretton Woods institutions - the agreement between the International Monetary Fund and the World Trade Organization, and the agreement between the International Bank for Reconstruction and Development, the International Development Association, and the World Trade Organization. ${ }^{64}$ These agreements, which were approved by the WTO General Council at its meeting on November 7, 8, and 13, 1996, ${ }^{65}$ were intended to strengthen the WTO's relationship with IMF and the World Bank. The WTO has concluded two more agreements: one with the World Intellectual Property Organization ${ }^{66}$ and one with the World Organization for Animal Health (formerly the Office International des Epizooties). ${ }^{67}$

The relevance of such agreements has already been acknowledged in case law: the AB, in its report in Argentina - Textiles and Apparel, ${ }^{68}$ held that the agreement between the WTO and the IMF is legally relevant but that it does not modify, add to, or diminish the rights and obligations of members under the WTO Agreement. The agreements in questions are consequently not covered agreements in the sense of Appendix 1 to the DSU.

\section{The Treatment of Customary International Law in WTO}

Before we move to review the interpretative elements for WTO law, a few words on the treatment of customary law warranted. One WTO panel has discussed at length the relevance of customary international law in the WTO legal context, and in light of this report, we are

EC-Bananas III, supra note 43, para. 7.4. Given that the export revenue for numerous developing countries risked being heavily affected by the outcome of the dispute, the panel agreed to the request. Id., paras. 7.8, .9.

${ }^{61}$ See Mavroidis, supra note 22, for a detailed account of the amici participation saga and the current conditions for participation.

${ }^{62}$ See Bartels, supra note 16.

${ }^{63}$ As per Article IV:2 of the WTO Agreement, the General Council can exercise the functions of the Ministerial Conference, the highest organ in the WTO institutional setting, when the latter does not meet.

${ }^{64}$ General Council Decision, Agreements Between the WTO the IMF and the World Bank, WTO Doc. WT/L/195 (Nov. 18, 1996).

${ }^{65}$ The legal basis for these agreements is Article III:5 of the WTO Agreement.

6635 ILM 754 (1996).

${ }^{67}$ WTO Doc. WT/L/272 (July 8, 1998).

${ }^{68}$ Panel Report, Argentina-Measures Affecting Imports of Footwear, Textiles, Apparel and Other Items, para. 72, W T/DS56/R (adopted Apr. 22, 1998), modified by Appellate Body Report, Argentina-Measures Affecting Imports of Footwear, Textiles, Apparel and Other Items, WT/DS56/AB/R (adopted Apr. 22, 1998). 
compelled to devote some paragraphs to the issue. Numerous other reports have made extensive reference to general principles of law that are not referenced in the VCLT. These reports will be discussed in a separate subsection.

Customary international law plays a specific role in WTO dispute settlement by virtue of DSU Article 3.2, which specifies that the purpose of dispute settlement is to clarify the provisions of the WTO Agreement "in accordance with customary rules of interpretation of public international law."

The 2000 panel report in Korea-Procurement ${ }^{69}$ discussed the relevance of customary international law (other than treaty interpretation) to the WTO legal order. In particular, this report examined the concept of nonviolation complaints ${ }^{70}$ in the light of customary international law_-and more specifically, in relation to pacta sunt servanda.

Customary international law applies generally to the economic relations between the WTO Members. Such international law applies to the extent that the WTO treaty agreements do not "contract out" from it. To put it in another way, to the extent that there is no conflict or inconsistency, or an expression in a covered WTO agreement that implies differently, we are of the view that the customary rules of international law apply to the WTO treaties and to the process of treaty formation under the WTO.

With this very important statement, the panel report suggests that general customary international law is always relevant unless the covered agreements have explicitly contracted out from it. The natural consequence would be that, since the content of customary international law contains elements additional to WTO contractual rights and obligations, the covered agreements and the incorporated agreements are not exclusive sources of law applicable in WTO adjudication; customary international law must also be considered a source of WTO law.

Statements such as those in Korea-Procurement have never been repeated in subsequent case law. Nevertheless, the report's potential use for extending the sources of WTO law to cover customary international law should not be exaggerated: a context-specific reading of this panel report suggests that its findings were not made with respect to an autonomous source of law (à la Higgins), ${ }^{71}$ but with respect to a general principle that has attained the status of customary international law.

Even without its being specifically addressed in the case law, the overall relevance of customary international law in the WTO legal order has continued to be an active topic in the legal literature. Pauwelyn, ${ }^{72}$ for example, makes the case in favor of constructing WTO law as a part of the whole- -with the whole being public international law. If such an approach entails using interpretative elements from the wider public international law, then few would argue with it.

${ }^{69}$ Panel Report, Korea-Measures Affecting Government Procurement, para. 7.96, WT/DS163/R (adopted June 19, 2000) [hereinafter Korea-Procurement].

70 Through this instrument, trading nations might be compelled to compensate their (negatively) affected trading partners, even though they have committed no illegality. The leading example is compensation for (external negative) effects of subsidization: domestic subsidies are not illegal in the WTO legal order, but a nation that subsidizes, say, tomatoes after it has agreed to reduce its import duty on this product, is harming the foreign producer who might legitimately not have expected this subsidy. Compensation in such a case is necessary, not only in order to protect the bona fides trading partner who negotiated the ten percent concession, but also because the system wants thus to ensure that the incentive to negotiate further trade liberalization will not be put into question by such (legal) acts.

71 See HigGINS, supra note 7.

72 JOOST PAUWELYN, CONFLICTS OF NORMS IN PUBLIC INTERNATIONAL LAW (2003). 
If, however, the suggestion is that by referring to customary international law, we are looking for autonomous sources of law additional to the covered (and the incorporated) agreements, then the discussion become tricky, at least within WTO dispute settlement. A primary problem concerns the identification of the relevant customary international law: which customary international law is relevant? To respond to this question, we need a precise definition of the customary international law (other than jus cogens, of course) that binds all $153 \mathrm{WTO}$ members. ${ }^{73}$

Some of that customary international law has been codified: the VCLT, the UN General Assembly resolution on state responsibility, ${ }^{74}$ and the 1982 Convention on the Law of the Sea. ${ }^{75}$ The last of these could be relevant for the discussion of rules of origin, though at this stage there is nothing like a substantive agreement on rules of origin in the WTO.

The General Assembly resolution on state responsibility has been referred to in some WTO disputes and, in extenso, in the arbitrator's report in U.S.—FSC (Article 22.6-U.S.). ${ }^{76}$ It was referred to as supplementary means supporting the interpretative decision on remedies, and not as an autonomous source of law. ${ }^{77}$ The resolution in question codifies customary international law in the field of state responsibility and is the product of an effort extending over five decades. ${ }^{78}$ The International Law Commission's report clarifies numerous issues that were left unspecified in the DSU: for example, retroactive remedies — in the sense that damages will be calculated from the point in time when the illegality was committed-are customary international law, and so is the calculation of both damnum emergens (damage already suffered) and lucrum cessans (expectation value, forgone gains) as part of the compensation due in case of breach of contract.

Nothing, of course, stops the WTO membership from explicitly deviating from customary law (other than jus cogens). Indeed, since custom and treaty are of equal value, it is the lex posterior principle that will determine which law takes precedence. ${ }^{79}$ Nevertheless, although the DSU is highly

73 The current list of members and the dates that they joined the organization can be found at $<$ http://www. wto.org/english/thewto_e/whatis_e/tif_e/org6_e.htm>.

${ }^{74}$ General Assembly Resolution 56/83 adopted the International Law Commission's Articles on the Responsibility of States for Internationally Wrongful Acts.

${ }^{75}$ UN Convention on the Law of the Sea, opened for signature Dec. 10, 1982, 1833 UNTS 397, reprinted in 21 ILM 1261 (1982).

${ }^{76}$ Arbitration Report, United States-Tax Treatment for "Foreign Sales Corporations," Recourse by Article 22.6 of the DSU and Article 4.11 of the SCM Agreement by EC, W T/DS108/ARB (adopted Aug. 30, 2002) [hereinafter U.S._FSC].

${ }^{77}$ Recall our discussion of HIGGINS, see supra note 7, and the point made there that general principles of law serve the purpose of interpreting other sources of law rather than creating autonomous rights and obligations. Admittedly, the arbitrator's reference to the General Assembly resolution in U.S.—FSC is cryptic and could lend support to those taking the view that the reference to the resolution was in the context of VCLT Article 31; that is, the arbitrator considered the resolution to be a relevant rule of public international law, or context to the WTO, and for this reason recourse to it was compulsory. My own view, however, is that the majority of the references to the resolution simply confirm the conclusion that the arbitrator had already reached about the remedy to recommend in the case; that is, the arbitrator first decided (without reference to the resolution) what remedy to recommend, and then justified that choice by referring to the resolution. If anything, the resolution was used as supplementary means of interpretation, as per VCLT Article 32.

${ }^{78}$ Various jurisdictions around the world have repeatedly acknowledged the customary nature of the obligations contained therein.

${ }^{79}$ The General Assembly resolution was passed after the DSU, so it could be argued that it is lex posterior to it. However, it only declares what seems to have been the customary standard for compensation for many years before the enactment of the DSU (see, for example, the judgment of the Permanent of International judgment in Factory at Chorzów (Ger. v. Pol.), 1928 PCIJ (ser. A) No. 17 (Sept. 13). In this vein, the DSU did not deviate from prior customary international law. 
incomplete-in the sense that it does not address all the issues addressed in the General Assembly resolution on state responsibility - the DSU does not explicitly deviate from the resolution.

DSU Article 19, the overarching provision, indicates that panels will recommend that parties bring their measures into compliance, when appropriate, but will not prescribe particular courses of action. DSU Article 22.4, as well as SCM Article 4.10, ${ }^{80}$ which deal with the calculation of damages, reflect the proportionality principle-the essence of the calculation of damages in the General Assembly resolution. Consequently, as to the basic principle, there is symmetry across the WTO agreements and the General Assembly resolution. The W TO legal framework does not address any other questions regarding the calculation of damages. Those matters were left to practice.

WTO practice suggests that, contrary to what is the case in customary international law, damages will be calculated from the end of the implementation period and not from the earlier moment when the illegality occurred. In the GATT years, there was no provision corresponding to DSU Article 19: Petersmann ${ }^{81}$ identifies only five cases where retroactive remedies were recommended ( 5 out of over 120 cases, in which, by Hudec's counting, the complaining parties prevailed in the majority of cases). ${ }^{82} \mathrm{WTO}$ practice lends further support to the argument that remedies in the WTO legal system are de facto of prospective nature only. ${ }^{83}$

At the end of the day the question is: how should the legislative silence in DSU Article 19 be understood? The WTO will, by virtue of Article XVI of the WTO Agreement, be guided by GATT practice. When turning to GATT practice, panels have found a mixed record: as noted above, a few reports embraced retroactivity, but most did not. This record could raise legitimate doubts as to the continuing relevance of retroactivity in the WTO era. Risk-averse agents have comfortably sought refuge in the less intrusive (as far as national sovereignty is concerned) mode of calculating damages. ${ }^{84}$ GATT/WTO practice thus lends support to the

80 The linguistic differences between the two provisions suggest that damages will be calculated in a slightly more generous manner under the SCM Agreement. Both provisions stick to proportionality, however, and a footnote to SCM Article 4.10 explicitly states that no recourse to disproportionate countermeasures is permissible under that article. See Petros C. Mavroidis, Remedies in the WTO Legal System: Between a Rock and a Hard Place, 11 EUR. J. INT'L L. 763 (2000).

${ }^{81}$ Ernst-Ulrich Petersmann, International Competition Rules for the GATT-MTO World Trade and Legal System, 35 J. WORLD TRADE 27 (1993).

${ }^{82}$ ROBERT E. HUDEC, ENFORCING INTERNATIONAL TRADE LAW (1993). It is probably a quixotic test to try to explain why this practice has emerged, since so many explanatory variables are potentially at work. It seems to me, however, that the composition of panels is largely responsible. There are two important consequences of the selection process for the panelists, who were usually delegates in Geneva and agreed by the parties. First, they were likely to be sensitive to the parties own preferences and interests, and the parties generally have a common incentive not to "rock the boat" in view of the uncertainty as to who will commit illegalities in the future and potentially be subject to subject to retroactive damages. Second, since the panelists were not necessarily professional lawyers, they were not trained to think of remedies as involving an effort to restore the status quo ante. With regard to this latter point, there is a correlation between the establishment of a GATT legal office (with trained lawyers) (1982, in Hudec's (1993) narrative, supra) and the beginning of recommendations for retroactive remedies.

${ }^{83}$ With one exception only, panels and arbitrators (operating under DSU Article 22.6) alike have recommended prospective action. Regrettably so, I believe, on both doctrinal grounds, as mentioned here, and from a policy perspective since such remedies substantially undermine the incentive to comply. Having stated that, one should probably keep in mind that the $\mathrm{AB}$ has so far had no opportunity to pronounce on this score.

${ }^{84}$ As noted above, if providing an incentive to comply is the paramount consideration, then remedies should be retroactive. In Punishments and Dispute Settlement in Trade Agreements (2001), at < http://www.econ.ku.dk/epru/files/wp/ WEB-blaa-2001-14.pdf>, however, Wilfried Ethier has taken the view that, in light of the uncertainty as to who will be the winner in dispute adjudication, the common incentive of the membership is to opt for weak, rather than strong, remedies. This reinforces the point made above, see supra note 82 , concerning the selection of panelists. 
argument that customary international law has not been followed in the WTO on this particular issue of damages_ an outcome with which the majority of WTO membership seems at ease. ${ }^{85}$

Moving away from codified customary law presents us with important evidentiary issues. Take for example, the precautionary principle, which has been codified in some treaties. The panel report in EC-Hormones ${ }^{86}$ held the view that, assuming arguendo that the precautionary principle is customary international law, it would not override explicit provisions of the covered agreements that were intended to codify it. This conclusion was affirmed by the AB, which noted that the status of the precautionary principle in international law is still very much the subject of debate. The $\mathrm{AB}$ also stated that while the precautionary principle might have crystallized into a general principle of customary international environmental law, it is less than clear whether it has been widely accepted as a principle of general or customary international law. At the same time, whether or not the precautionary principle might have that status, the $\mathrm{AB}$ ended up stressing its relevance in the interpretation of WTO norms.

More generally, WTO case law has not further clarified issues left unanswered by KoreaProcurement concerning the role of customary law in WTO adjudication. ${ }^{87}$ Note however, that over 200 reports in the WTO era and over 120 panel reports in the GATT era did not identify any custom other than good faith as a source of GATT/WTO law. If there were such sources of law relevant to GATT/W TO adjudication, one would expect that in the sixty years of multilateral trade relations that gave birth to hundreds of court (panel) proceedings, arguments invoking such law would surely have been advanced by the interested parties. They were not.

\section{General Principles of Law in the WTO Legal Order}

The nature of general principles. ${ }^{88}$ The panel report in EC-Pipe Fittings ${ }^{89}$ held that a general principle of law, by its very nature, cannot substitute for a detailed contractual provision.

We are conscious that the requirement in Article 3.1 to conduct an "objective examination" on the basis of "positive evidence" is that the investigating authorities examination

85 To avoid any misunderstandings, I am not describing here the law as it should be, but rather as it is.

${ }^{86}$ Panel Report, EC-Measures Concerning Meat and Meat Products (Hormones), WT/DS26/R/USA (adopted Feb. 13, 1998), modified by Appellate Body Report, EC-Measures Concerning Meat and Meat Products (Hormones), paras. 120-25, W T/DS26/AB/R (adopted Feb. 13, 1998) (reported by David A. Wirth at 92 AJIL 755 (1998)) [hereinafter EC-Hormones].

${ }^{87}$ See supra note 69 and accompanying text. It is difficult to state how much the WTO legal regime has missed out so far as a result of this attitude. In Customary International Law as a Judicial Tool for Promoting Efficiency, in THE IMPACT OF INTERNATIONAL LAW ON INTERNATIONAL COOPERATION 85 (Eyal Benvenisti \& Moshe Hirsch eds., 2004), Eyal Benvenisti points to the possibility of using customary international law to promote more efficient equilibria among those participating. One important condition in his scheme however, concerns the role of the judge. Without advocating a judge akin to Dworkin's Hercules, he, too, envisages a well informed and alert judge. To my mind — and for institutional reasons, since panelists are ad hoc and AB members part timers) — much remains to be done in this context before we can reap similar benefits in the WTO. I will return to this issue later.

${ }^{88}$ It was difficult to decide whether general principles of law should be treated here, under sources of law applicable in W TO adjudication, rather than in part III, where we discuss interpretative elements. Some of the general principles mentioned here do interpret the sources of law. For example, in dubio mitius amounts to a presumption that no sovereignty has been transferred when the letter of the law is unclear. But some general principles do not have this function. For example, estoppel and res judicata do not interpret rules of law; instead, they limit the competence of an adjudicating body to decide certain questions. It is the heterogeneity of general principles of law that persuaded me that they should be discussed here as a separate category of law applicable in WTO adjudication.

${ }^{89}$ Panel Report, EC_-Pipe Fittings, supra note 51, para. 7.292. 
conform to the dictates of the basic principles of good faith and fundamental fairness. The investigating authority must therefore ensure an even-handed treatment of the information and data on the record of the investigation. ${ }^{90}$

This passage reflects, in a general manner, the attitude of WTO adjudicating bodies toward general principles of law. The panel used such general principles in order to interpret the requirement of an "objective examination." In what follows, I identify the general principles that have been acknowledged as legally relevant in the WTO legal order.

Estoppel. The first comprehensive discussion of estoppel appeared in the GATT panel report in U.S. - Softwood Lumber II. ${ }^{91}$ In that case, the parties to the dispute (Canada, United States) had concluded a memorandum of understanding (MOU), and the question, inter alia, before the panel concerned the extent to which the parties, by signing the MOU, had waived their rights under the GATT and were thus estopped from any further action. Although the panel discusses this question in extenso in its report, it refrained from deciding the issue in light of the dispute's particular factual setting. Because of the panel's extended discussion of this issue, however, it is reasonable to infer that the panel was saw the principle of estoppel as having some relevance within the GATT legal framework.

Since that time, several WTO panels have discussed estoppel. No consistent view emerges from the case law, however; the legal relevance has depended on various factors, ranging from the subject matter of the particular case to the evidence relating to the behavior of the WTO member allegedly bound by the estoppel. The first discussion can be found in the 2000 panel report in Guatemala-Cement II. ${ }^{92}$ After the AB rejected Mexico's initial complaint, Mexico introduced a new complaint against the same practice. At that point Guatemala argued that Mexico was estopped from pursuing that new complaint. The panel disagreed, reasoning that the estoppel principle is relevant, only if the complaining party had clearly consented to the particular behavior in question, which Mexico had not. ${ }^{93}$

Along the same lines, the 2003 panel report in Argentina-Poultry Antidumping Duties ${ }^{94}$ reviewed the estoppel principle as a source restraining its jurisdiction. In concreto, Argentina argued that Brazil was estopped from submitting the instant dispute to a WTO panel since the very same dispute had already been adjudicated by a MERCOSUR panel (the regional integration scheme in which both Argentina and Brazil participate). The WTO panel dismissed Argentina's argument because, inter alia, in its view DSU Article 3.2 did not require panels to rule in any particular way and thus to conform their own decisions to those by other adjudicating forums. The panel did accept, however, the parameters of the estoppel principle as presented by Argentina-in particular, that estoppel applied in circumstances where one party makes a statement that is clear and unambiguous, voluntary, unconditional, authorized, and relied on by the other party in good faith.

${ }^{90}$ I understand that reference to "basic principles" is tantamount to general principles of law.

${ }^{91}$ Panel Report, United States—Measures Affecting Imports of Softwood Lumber from Canada, paras. 308 -25, SCM/162 (adopted Oct. 27, 1993).

${ }^{92}$ Panel Report, Guatemala-Definitive Anti-Dumping Measure on Grey Portland Cement from Mexico, paras. 823, $824 \&$ n.791, W T/DS156/R (adopted Nov. 17, 2000).

${ }^{93}$ To be sure, Guatemala was effectively arguing ne bis in idem. "Estoppel" is a different concept: it can be the consequence of ne bis in idem, but it is also relevant in circumstances other than ne bis in idem as well. For example, in the ICJ's Nuclear Tests cases (Austl. v. Fr.; N.Z.v. Fr.), 1974 ICJ REP. 253 \& 457 (Dec. 20), estoppel is the consequence of a unilateral declaration to stop nuclear tests, and not of a prior court decision or arbitration.

${ }^{94}$ Panel Report, Argentina—Poultry Anti-dumping Duties, supra note 52, paras. 7.37, .38. 
More recently, the AB, in its 2005 report in EC_Export Subsidies on Sugar, ${ }^{95}$ had the opportunity to present its views on estoppel. Noting that it had never applied this principle, it took the view that if relevant at all, the principle had been narrowed down to DSU Articles 3.7 and 3.10, which require WTO members to exercise their judgment as to the fruitfulness of submitting a dispute. This analysis by the $\mathrm{AB}$, however, has nothing to do with the estoppel principle as it is known in public international law. The two DSU articles in question are conceptualized in terms of cost-benefit analysis, which would probably not be justiciable. By contrast, estoppel within public international law is conceived as an obstacle to submitting a claim, irrespective of the outcome of any possible cost-benefit analysis by the potential claimant. Following the AB's decision in EC_Export Subsidies on Sugar, it seems safe to conclude that, as things stand, the estoppel principle, as we know it in public international law, has no current place in the WTO legal regime. ${ }^{96}$

Res judicata. The panel report in India-Autos ${ }^{97}$ discussed res judicata extensively, holding that the principle has its place in the WTO legal order. This panel made it clear that there are stringent conditions attached to this principle; absent their satisfaction, it cannot be applied:

1. the measures challenged in the original and the subsequent disputes must be identical

2. the claims in the two disputes must be identical

3. the parties in the two disputes must be identical

If these three conditions are cumulatively met, then res judicata comes into play. No subsequent case, however, has applied the legal benchmark established through India-Autos. That benchmark is, it should be said, largely consonant with the understanding of this principle in public international law. ${ }^{98}$

Error. The panel report in Korea-Procurement ${ }^{99}$ is the only report that contains a comprehensive discussion of error. In that case the United States claimed that an error on its part had the effect of vitiating its consent to be bound by the terms of the agreement. The issue before the panel concerned the extent to which a Korean entity was obligated to abide by the disciplines of the WTO Agreement on Government Procurement. ${ }^{100}$ The panel discussed whether the error at hand was of such a nature as to accept the U.S. claim that it should not be considered to have given its consent. The panel concluded that the United States had itself contributed

${ }^{95}$ Appellate Body Report, European Communities-Export Subsidies on Sugar, WT/DS265/AB/R, W T/DS266/AB/R, \& W T/DS283/AB/R (adopted May 19, 2005) [hereinafter EC_Export Subsidies on Sugar].

${ }^{96}$ Note that in similar cases ICJ practice shows that unilateral declarations have been acknowledged the force of estoppel, thereby making it impossible for the declaring states to exercise the rights that they promised not exercise. See Legal Status of Eastern Greenland (Den. v. Nor), 1933 PCIJ Series A/B, no. 53, at 71 (Apr. 5) (discussing Ihlen Declaration); Nuclear Tests.

${ }^{97}$ Panel Report, India-Measures Affecting the Automotive Sector, paras. 7.54-.66, WT/DS146/R, WT/DS175/R \& corr.1 (adopted Apr. 5, 2002).

98 The difference between res judicata and estoppel is as follows: in the former, the forum is the same (in the original and the subsequent litigation), whereas in the latter, the forums are different, so that a country might be estopped from submitting a complaint before a particular forum because a different forum has already pronounced on the issue.

${ }_{99}$ Panel Report, Korea-Procurement, supra note 69, paras. 7.123-.126.

${ }^{100}$ April 15, 1994, W TO Agreement, supra note 5, Annex 4B, in THE LEGAL TEXTS, supra note 5. 
to the error and was therefore obligated to carry out the contractual terms (that is, the error was not excusable). The panel's entire analysis is predicated on its understanding and interpretation of VCLT Article 48. ${ }^{101}$

Non adimplenti contractus. ${ }^{102}$ In Argentina-Poultry Anti-dumping Duties ${ }^{103}$ Argentina argued, inter alia, that other WTO members had been practicing what Argentina was being accused of, but without being punished. Argentina was arguing, in effect, that it should not be punished since others were also not respecting the relevant portion of the WTO contract. The panel responded that the dispute before it concerned only Argentina's practices:

Argentina asserts that the methodology used by the [Department of Unfair Trading Practices and Safeguards] has also been used by other WTO Members. Even assuming for the sake of argument that Argentina is correct, this argument is nevertheless irrelevant. In this dispute, we must determine the conformity of Argentina's methodology (and not that of other WTO Members) in light of the relevant provisions of the [Anti-dumping] Agreement.

As a result, Argentina could not invoke non adimplenti contractus as a source restraining the panel's jurisdiction.

Good faith (bona fides). Numerous reports refer to the obligation to perform the WTO treaty in good faith, as is also stipulated in VCLT Article 26 (pacta sunt servanda). What exactly this obligation entails has nevertheless been discussed only on a few occasions: the panel report in Korea-Procurement ${ }^{104}$ contains reference to the good faith (bona fides) principle as one of public international law that must be taken into account by WTO adjudicating bodies.

There is some case law concerning the connection between violations of the WTO Agreement and the principle of good faith. Consider, for example, the panel report in EC-Pipe Fittings, ${ }^{105}$ where the panel took the defendant to be acting in good faith even though some confidential information was not submitted to the panel, and the reason for not submitting such information was judged unsatisfactory by the panel itself. Similarly, in U.S. - Offset Act (Byrd Amendment), ${ }^{106}$ the $\mathrm{AB}$ asserted that a mere violation of a provision of a WTO Agreement does not in and of itself amount to a violation of the principle of good faith. So far, no WTO case law has suggested that a member may have acted in bad faith.

In dubio mitius. The dubio mitius principle has been invoked in more than one case, the leading one being the $E C$ - Hormones $\mathrm{AB}$ report. ${ }^{107}$ There, the $\mathrm{AB}$ reversed the panel's understanding concerning the allocation of the burden of proof when a WTO member deviates from an international standard (of those mentioned in the SPS Agreement). Contrary to what the panel

${ }^{101}$ A word of caution is warranted here. This panel is idiosyncratic, an outlier: no other panel has shown so much deference toward customary law. The ad hoc selection process of panelists enables such outcomes. The assistance that the WTO secretariat provides to panels is a means of ensuring that such deviations from "orthodoxy" will not be frequent.

102 By virtue of this principle, a promisee can lawfully breach its promise if the promisor has neglected its own.

${ }^{103}$ Panel Report, Argentina-Poultry Anti-dumping Duties, supra note 52, para. 7.79.

${ }^{104}$ Panel Report, Korea-Procurement, supra note 69.

105 Panel Report, EC_Pipe Fittings, supra note 51, para. 7.307.

${ }^{106}$ Appellate Body Report, United States_Continued Dumping and Subsidy Offset Act of 2000, para. 298, WT/DS217/AB/R, W T/DS234/AB/R (adopted Jan. 27, 2003) (reported by Mark L. Movsesian at 98 AJIL 150 (2004)) [hereinafter U.S._-Offset Act (Byrd Amendment)].

107 Appellate Body Report, EC-Hormones, supra note 86, paras. 154, 165. 
had held, the $\mathrm{AB}$ took the view that an adjudicating body cannot simply assume that, in presence of two possible readings of the same provisions, WTO members opted for the relatively more onerous of the two. The $\mathrm{AB}$ based its conclusion on the maxim in dubio mitius:

We cannot lightly assume that sovereign states intended to impose upon themselves the more onerous, rather than the less burdensome, obligation by mandating conformity or compliance with such standards, guidelines and recommendations. To sustain such an assumption and to warrant such a far-reaching interpretation, treaty language far more specific and compelling than that found in Article 3 of the SPS Agreement would be necessary.

Citing numerous public international law books and articles that discuss the principle in dubio mitius, the $\mathrm{AB}$ also noted that the "interpretative principle of in dubio mitius, [is] widely recognized in international law as a 'supplementary means of interpretation." Thus, this case opens the WTO door to in dubio mitius and also, at the same time, clarifies that it is to be considered a supplementary means of interpretation.

In a nutshell, in WTO adjudication, general principles of law have been used extensively, though in most cases as interpretative elements for the sources of WTO law. In theory-but as yet, not in practice - general principles can be used as factors limiting a complainant's right to relief. In Korea-Procurement, the complainant was, in fact, refused relief because of a violation of a general principle of law, but that was the only such case. It has proved to be an outlier whose approach to public international law has not been taken up in subsequent cases.

\section{INTERPRETATIVE ELEMENTS}

In this part I have two objectives: (1) to lay out the process for identifying interpretative elements for the WTO Agreement and its covered agreements, and (2) to show that, because WTO adjudicating bodies are not free to choose their mode of interpretation but must abide by customary international law in this respect, ${ }^{108}$ the identification process itself also determines the legal value of the various interpretative elements used.

We begin off our discussion by explaining the interpretative constraint ${ }^{109}$ imposed on the WTO adjudicating bodies.

\section{The Vienna Convention on the Law of Treaties Enters the WTO}

DSU Article 1 states: "The rules and procedures of this Understanding shall apply to disputes brought pursuant to the consultation and dispute settlement provisions of the agreements listed in Appendix 1 to this Understanding (referred to in this Understanding as the 'covered agreements').”

When adjudicating a dispute between two WTO members, a WTO adjudicating body will essentially be requested to complete the contract by providing dispute-specific information. The

\footnotetext{
${ }^{108}$ Contrary to the ICJ, WTO adjudicating bodies cannot judge ex aequo et bono.

${ }^{109}$ DSU Article 3.2 not explicitly refer to the VCLT. The AB understood the reference to customary rules of interpretation to imply reference to VCLT.
} 
terms of reference (TOR) for dispute-adjudication are enshrined in DSU Article 7: 110 "To examine, in the light of the relevant provisions in (name of the covered agreement(s) cited by the parties to the dispute), the matter ...."

When called to adjudicate, a WTO adjudicating body is not free to choose any legal interpretation that it deems appropriate. It must interpret the covered agreements by observing the discipline embedded in DSU Article 3.2, which reads in full:

The dispute settlement system of the WTO is a central element in providing security and predictability to the multilateral trading system. The Members recognize that it serves to preserve the rights and obligations of Members under the covered agreements, and to clarify the existing provisions of those agreements in accordance with customary rules of interpretation of public international law. Recommendations and rulings of the DSB cannot add to or diminish the rights and obligations provided in the covered agreements.

The $\mathrm{AB}$, in the first case before it-U.S. - Gasoline ${ }^{111}$ — held that all covered agreements are part of one agreement, the WTO Agreement, and it also understood the reference to customary rules of interpretation of public international law to correspond to the rules contained in the VCLT.

VCLT Article 31 mentions that a treaty shall be interpreted in accordance with (1) the ordinary meaning of its terms (2) in their context, taking into account (3) the object and the purpose of the treaty, (4) relevant subsequentpractice, (5) subsequent agreements on the same subject matter, and (6) any relevant rules of public international law applicable in the relations between the parties, while VCLT Article 32 adds that (7) under specific conditions, recourse to supplementary means of interpretation (travaux préparatoires) can take place.

WTO adjudicating bodies have not relied exclusively on the references explicitly mentioned in the VCLT. In interpreting the covered agreements, those bodies have occasionally used the lex specialis — a standard under which those bodies have privileged their recourse to the covered agreement that regulates a particular issue in more detail. ${ }^{12}$ Lex specialis is not explicitly included as such in the VCLT, but it is consonant with the principle of effective treaty interpretation (ut regis valeat quam paereat), which provides the cornerstone of the VCLT: were one not to start from the rule that specifically regulates a particular transaction (and were to privilege, instead, the application of the more general rule), one risks making such specific rules redundant. In the words of the $\mathrm{AB}$ in U.S._-Gasoline: "An interpreter is not free to adopt a reading that would result in reducing whole clauses or paragraphs of a treaty to redundancy or inutility. ${ }^{113}$ In this vein, the panel in its report in Canada-Patent Term ${ }^{114}$ tested whether the

\footnotetext{
${ }^{110}$ Unless special TOR have been agreed between the parties - an infrequent occurrence. For an example, see Appellate Body Report, Brazil-Measures Affecting Desiccated Coconut, WT/DS22/AB/R (adopted Mar. 20, 1997).

${ }^{111}$ Appellate Body Report, United States-Standards for Reformulated and Conventional Gasoline, at 15, WT/DS2/AB/R (adopted May 20, 1996) (reported by Maury D. Shenk at 90 AJIL 669 (1996)) [hereinafter U.S.Gasoline].

112 See, e.g., Panel Report, EC-Trade Description of Sardines, WT/DS231/AB/R (adopted Oct. 23, 2002), modified by Appellate Body Report, EC-Trade Description of Sardines, WT/D231/AB/R (adopted Oct. 23, 2002) [hereinafter EC-Sardines].

${ }^{113}$ Appellate Body Report, U.S.-Gasoline, supra note 111, at 23.

${ }^{114}$ Panel Report, Canada-Term of Patent Protection, para. 6.50, WT/DS170/R (adopted Oct. 12, 2000); Appellate Body Report, Canada-Term of Patent Protection, WT/DS170/AB/R (adopted Oct. 12, 2000).
} 
interpretation it reached on one TRIPS provision rendered redundant other related TRIPS provisions. ${ }^{115}$

One can thus find space for lex specialis in the VCLT system. The same cannot be said, however, for other devices that the $\mathrm{AB}$ has occasionally used: one would be hard pressed to bring the principle of evolutionary interpretation, used by the $\mathrm{AB}$ in U.S.-Shrimp, within the four corners of the VCLT system. ${ }^{116}$ There, the AB, borrowing from some very infrequently used jurisprudence of the International Court of Justice (ICJ), held that the term exhaustible natural resources should be understood to cover living organisms (since this term is evolutionary and not static, at least in the eyes of the AB) - and not simply nonliving materials, as the negotiating history of GATT Article XX(g) would have suggested. Such examples are nevertheless infrequent; the VCLT emerges as the main platform of interpretation in WTO practice. ${ }^{17}$

The AB has made reference not only to VCLT Articles 31 and 32, but also to Article 33, which deals with treaties signed in more than one language: Article XVI of the WTO Agreement, which acknowledges the English, French, and Spanish to be its authentic languages. But then, which version should be privileged in case of differences in the three texts? VCLT Article 33 stipulates that, in case a treaty has been authenticated in more than one language, the terms of the treaty shall be presumed to have the same meaning in each linguistic version. WTO adjudicating bodies, in the overwhelming majority of the cases, have used English as the working language. ${ }^{118}$ There is by now evidence that the $\mathrm{AB}$ has sometimes examined the French and the Spanish text to confirm a decision reached using the English text. ${ }^{119}$

${ }^{115}$ For the same reason, the AB privileged the application of the Agreement on Technical Barriers to Trade (TBT Agreement), Apr. 15, 1994, W TO Agreement, supra note 5, Annex 1A, in THE LEGAL TEXTS, supra note 5, at 138, over the GATT in its EC - Asbestos and EC — Sardines jurisprudence. Appellate Body Report, EC-Measures Affecting Asbestos and Asbestos-Containing Products, WT/DS135/AB/R (adopted Apr. 5, 2001) (reported by David A. Wirth at 96 AJIL 435 (2002)), modifying Panel Report, EC-Measures Affecting Asbestos and AsbestosContaining Products, W T/DS135/R (adopted Apr. 5, 2001) [hereinafter EC-Asbestos]; Appellate Body Report, EC-Sardines, supra note 112. To be fair, no problem would exist at all if lex specialis was practiced only as a means of ordering the various provisions that would, in any event, be cumulatively examined. But that has not always happened. Earlier WTO panels adopted a very narrow view of the term "conflict" and also exercised judicial economy. A good recent example is the panel report on $E C$ - Asbestos, which examined the consistency of the French measure only under GATT Article III:4 and not under the TBT Agreement. This approach could have been quite problematic had the measure at hand been nondiscriminatory but unnecessary: whereas GATT Article III: 4 requires that domestic instruments be nondiscriminatory, the TBT Agreement requires that a subset of them (in particular, those coming under the purview of the TBT Agreement) be necessary (that is, that in terms of impact on trade transactions, they represent the least restrictive option reasonably available to the regulating state). In this context a nondiscriminatory, but unnecessary, measure would thus pass the test of legitimacy under GATT Article III:4. Starting the analysis from the lex specialis avoids such problems, even if all the potentially applicable provisions have not been cumulatively reviewed.

${ }^{116}$ Appellate Body Report, United States-Import Prohibition of Certain Shrimp and Shrimp Products, para. 130, W T/DS58/AB/R (adopted Nov. 6, 1998) (reported by Gregory Shaffer at 93 AJIL 507 (1999)) [hereinafter U.S-Shrimp]. This report may be a unique instance of evolutionary interpretation in WTO dispute settlement.

117 This is not to suggest that GATT panels never used the VCLT. The creation of the Legal Affairs Division in the eighties in the GATT marked the turning point in this direction and an adoption of VCLT-friendly interpretations. See HUDEC, supra note 82.50. On the negotiating history of GATT ArticleXX(g), see DOUGLAS A. IRWIN, Petros C. MAVROIDIS, \& AlAN O. SyKES, THE GENESIS OF THE GATT (2008).

${ }^{118}$ A notable counterexample is the panel proceedings in EC-Asbestos.

119 See Appellate Body Report, EC_-Price Band System and Safeguard Measures Relating to Certain Agricultural Products, para. 271, W T/DS207/AB/R (adopted Oct. 23, 2002); Appellate Body Report, EC_Anti-dumping Duties on Imports of Cotton-Type Bed Linen from India, para. 123, WT/DS14/AB/R (adopted Mar. 12, 2001). 
The AB has further clarified — in U.S. — Softwood Lumber IV $V^{120}$ — that in accordance with VCLT Article 33, it should: "seek the meaning that gives effect, simultaneously, to all the terms of the treaty, as they are used in each authentic language." This approach would suggest that the treaty interpreter should privilege interpretations that overlap in the three different texts. In its report in EC-Tariff Preferences, ${ }^{121}$ however, the $\mathrm{AB}$ privileged the terms used in the French and the Spanish texts ("as defined"), which, to its own admission, reflected stronger, more obligatory language than the terms used in the English text ("as described"). In light of the narrow interpretative space between described and defined in the context at hand, one would probably be ill advised to accord too much importance to this finding.

Interpreting and applying the VCLT is not exact science; depending on the weight one places on one (or more) of its elements, a different outcome is possible. One can also, at least nominally, use all the mandated references while having already decided the issue under one of them. It is not the purpose of our discussion here to evaluate, in detailed manner, the use of the VCLT by WTO adjudicating bodies. Nevertheless, I will present a description and general assessment — a necessary prelude to our discussion on how interpretative elements are to be identified. I will try to make three points in what immediately follows:

1. WTO adjudicating bodies have relied heavily on what they understand to be the ordinary meaning of the terms, and much less on elements such as context, state practice, or subsequent agreements.

2. When in doubt, they prefer to classify interpretative elements under supplementary means. This approach is obviously in line with their incentive structure to maintain maximum flexibility in the future; it is, unfortunately, on occasion, incorrect.

3. The treatment of identical references has, on occasion, been inconsistent across cases.

WTO adjudicating bodies have had extensive recourse to dictionary meaning of terms (with a particular inclination to use the Oxford English Dictionary). In the past, the reader of a report has sometimes been left with the impression that dictionary-based, but acontextual, interpretations have carried too much weight. ${ }^{122}$ It is probably counterproductive to revisit such examples in detail. Suffice it to say that WTO adjudicating bodies have applied the VCLT in a compartmentalized manner: starting from ordinary meaning as a self-standing or independent entity, they have often reached a substantive legal conclusion based solely on the Oxford English Dictionary - a conclusion that they confirm, in turn, through recourse to the other interpretative elements (context and so on). This approach is incorrect, however, under the very terms of the VCLT: the ordinary meaning of an expression cannot be determined in isolation; the ordinary meaning of a particular legal term can be understood only as it occurs in a particular sentence, which itself has to understood and evaluated in the context of the overall contract or

\footnotetext{
${ }^{120}$ Appellate Body Report, United States-Final Countervailing Duty Determination with Respect to Certain Softwood Lumber from Canada, para. 59, W T/DS257/AB/R (adopted Feb. 17, 2004) (reported by Chi Carmody at 100 AJIL 664 (2006)) [hereinafter U.S.-Softwood Lumber IV].

${ }^{121}$ Appellate Body Report, EC-Conditions for the Granting of Tariff Preferences to Developing Countries, para. 147, WT/DS246/AB/R (adopted Apr. 20, 2004) [hereinafter EC-Tariff Preferences].

122 See Trachtman, supra note 21; DAVID PALMETER \& PETROS C. MAVROIDIS, DisPUTE SETTLEMENT IN THE World Trade Organization: Practice AND Procedure (2004). Wittgenstein, unfortunately, was never an $\mathrm{AB}$ member.
} 
agreement to which it belongs. ${ }^{123}$ This consequence follows naturally from the realization that words are not invariant or static in meaning (as dictionaries sometimes want them to be); ${ }^{124}$ they have a life within a particular integrated context where they are lodged.

An inquiry into the context (that is, the rest of the agreement at the very least) ${ }^{125}$ will lead the judge to ask two centrally important questions:

\section{What did the framers have in mind when they passed this law?}

2. How did they conceive the realization of their stated objectives? ${ }^{126}$

Contextual interpretations will thus lead the WTO judge to inquire both as to the ends sought and the means to those ends. Importantly, words will be placed in their appropriate context and be used in order to serve the stated objectives: as Orwell wrote in his essay Politics and the English Language, "let the meaning choose the word, and not the other way around." WTO adjudicating bodies should, for example, be asking the question "What does the term like products mean in the context of disciplining domestic instruments within a trade agreement aiming to liberalize trade?" rather than attempting to determine the meaning of the term based on the many definitions of likeness to be found in the Oxford English Dictionary. ${ }^{127}$

The $\mathrm{AB}$ seems recently to have gotten it right in U.S. - Gambling, ${ }^{128}$ where it stated that equating dictionary definitions to the ordinary meaning of terms is too mechanical an approach. With good fortune, this realization might serve to guide future judges; my understanding of this U.S._- Gambling dictum is that WTO adjudicating bodies should break with the compartmentalized approach used before.

Finally, it will become obvious to the reader that the approach followed until now by WTO adjudicating bodies has an inescapable by-product: the use of fewer interpretative elements than a contextual approach would have required. ${ }^{129}$

${ }^{123}$ Eduardo Jiménez de Aréchaga, International Law in the Past Third of a Century, 159 RECUEIL DES COURS 1 (1978-I).

${ }^{124}$ There have been a number of papers criticizing the (often) exaggerated textualism to which the WTO adjudicating bodies adhere. None, to my mind, has done so as eloquently as Henrik Horn \& Joseph H. H. Weiler, European Communities - Measures Affecting Asbestos and Asbestos-Containing Products, in THE W TO CASE-LAW OF 200114 (Henrik Horn \& Petros C. Mavroidis eds., 2003).

125 And into other relevant documents, as explained below, see infra notes 130-46 and accompanying text.

${ }^{126}$ Contrary to teleological interpretation, which typically asks the first question, contextual interpretation does not risk imposing obligations on WTO members that the framers did not envisage in the first place. Jiminéz de Aréchaga, see supra note 123, explains persuasively why it was felt by the VCLT's drafters that teleological interpretations should be avoided. See also infra note 146 and accompanying text.

${ }^{127}$ Mavroidis offers specific examples where, following acontextual interpretations, the $\mathrm{AB}$ ended up imposing obligations that were, in all likelihood, not envisaged by the framers. Two prominent examples are the benchmark for calculating benefits in SCM Article 14, as discussed in U.S.-Softwood Lumber IV, supra note 120, and the discipline on export credits under Article 10 of the Agreement on Agriculture, as discussed in U.S._Upland Cotton, see infra notes 161-62 and accompanying text, are but two prominent examples). Petros C. Mavroidis, Legal Eagles? A Look into 10 Years of AB Case-Law (Discussion Paper No. 49, APEC Study Center, Columbia University) (2007). McRae has advanced additional arguments in favor of contextual interpretations. Donald McRae, The WTO in International Law: Tradition Continued or New Frontier? 3 J. INT'L ECON. L. 27 (2000).

${ }^{128}$ Appellate Body Report, United States-Measures Affecting the Cross-border Supply of Gambling and Betting Services, para. 166, W T/DS285/AB/R \& corr.1 (adopted Apr. 20, 2005) (reported by Joel P. Trachtman at 99 AJIL 861 (2005)) [hereinafter U.S._Gambling].

${ }^{129}$ This is so, because the W TO judge is typically not in doubt as to the meaning of a term following an evaluation of the ordinary meaning of the terms. The W TO judge will, thus not have to search actively for references to support the conclusion reached. 


\section{The VCLT as Means of Identifying and Classifying the Interpretative Elements}

We now turn to our discussion of interpretative elements. Through interpretation itself, WTO adjudicating bodies also identify the interpretative elements that they have used to determine a particular issue. Let us go back to the already cited example concerning the interpretation in U.S. - Shrimp of the term exhaustible natural resources appearing in GATT Article $\mathrm{XX}(\mathrm{g})$. Recourse (by the $\mathrm{AB}$ ) to the Convention on International Trade in Endangered Spe$\operatorname{cies}^{130}$ (CITES), which provides its own definition of the term, means that a multilateral environmental agreement (MEA) could serve as an interpretative element of a term used in the WTO Agreement. The interpretation of the covered agreements becomes thus the pathway that will lead us to the identification of the interpretative elements.

Relevance is the first step. The second step is the classification of the interpretative elements: the VCLT contains a hierarchy of the various elements; recourse to some of them is compulsory, whereas to others, optional. VCLT Article 32 clearly indicates that recourse to supplementary means of interpretation will be made only in accordance with the conditions included therein and, in any event, only after recourse to VCLT Article 31 has been made and has either proved fruitless or requires confirmation. Recourse to all elements included in the VCLT Article 31 list is compulsory, though they are arranged hierarchically — a point that the $A B$, echoing the VCLT's negotiating history, ${ }^{131}$ made clear in U.S. - Shrimp. ${ }^{132}$ In this context, the AB noted that the object and purpose of the treaty have an auxiliary function:

A treaty interpreter must begin with, and focus upon, the text of the particular provision to be interpreted. It is in the words constituting that provision, read in their context, that the object and purpose of the states parties to the treaty must first be sought. Where the meaning imparted by the text itself is equivocal or inconclusive, or where confirmation of the correctness of the reading of the text itself is desired, light from the object and purpose of the treaty as a whole may usefully be sought. ${ }^{133}$

It follows that, every time a WTO adjudicating body refers to an interpretative element under a particular heading of VCLT Articles 31-32, it has ipso facto prejudged its legal value as well.

${ }^{130}$ Convention on International Trade in Endangered Species of Wild Fauna and Flora, Mar. 3, 1973, 993 UNTS 243, 12 ILM 1085 (1973).

${ }^{131}$ Quoting from Jiménez de Aréchaga, supra note 123, at 165:

It is important to remark that "the object and purpose of the treaty" is mentioned not as an independent element as in the Harvard Draft Convention but at the end of paragraph 1 . This was done deliberately, in order to make clear that "object and purpose" are part of the context, the most important one, but not an autonomous element in interpretation, independent of and on the same level as the text, as is advocated by the partisans of the teleological method of interpretation.

${ }^{132}$ Appellate Body Report, U.S.-Shrimp, supra note 116, para. 114. There can be no dispute that a hierarchy exists between VCLT Articles 31 and 32 since the latter makes explicit that recourse to the supplementary means of interpretation is available only in accordance with the conditions it states. See section below on Supplementary Means.

133 This passage from the Appellate Body report in U.S. - Shrimp was cited in the panel report on EC - Chicken Cuts as evidence of the hierarchy among the various interpretative elements laid down in VCLT Article 31. Panel Report, EC-Customs Classification of Frozen Boneless Chicken Cuts, para. 7.92, WT/DS269/R, WT/DS269/R (adopted Sept. 27, 2005), modified by Appellate Body Report, EC-Customs Classification of Frozen Boneless Chicken Cuts, WT/DS269/AB/R, WT/DS286/AB/R (adopted Sept. 27, 2005) [hereinafter EC-Chicken Cuts]. 
Panels must, for example, always examine the relevance of an MEA, if they consider it to be a subsequent agreement, as per VCLT Article 31(3); if, instead, it is considered to be a supplementary means of interpretation, then recourse to the MEA is at their discretion. Since terms appearing in the VCLT are not always given a precise substantive content, however, ${ }^{134}$ such classification is not always a mechanic exercise.

Practice reveals that only on occasion have WTO adjudicating bodies explicitly identified the heading under which they have examined the various interpretative elements that they have used. Take, for example, the $\mathrm{AB}$ report in Korea-Dairy, ${ }^{135}$ which is quite representative: it discussed a GATT-adopted report to support its interpretation of the term unforeseen developments; we are left in the dark as to the classification of the GATT panel report under the headings of the VCLT. By the same token, in Chile-Price Band, ${ }^{136}$ where the AB discussed the term so as to afford protection appearing in GATT Article III:2, it referred to a series of previous WTO AB reports while stopping short of mentioning the relevance of such reports under the VCLT. The same could be said for many other reports. As a result, the classification exercise is largely left to the observer. To be sure, WTO adjudicating bodies have left no doubt with respect to some elements: the travaux préparatoires of the covered agreements have been consistently discussed under VCLT Article 32.

That said, the scope of most of the VCLT references is not in doubt: the ordinary terms of a treaty can apply only to the text of the covered agreements; the object and purpose refer to the object and purpose of a treaty as such — in our case, the WTO Agreement (including the stated object and purpose in various specific covered agreements - and is usually reflected in the preamble; and a time element distinguishes subsequent practice and subsequent agreement from all other elements reflected in the VCLT.

The substantive boundary between context and supplementary means of interpretation remains a matter of some dispute. Because the legal value of the two references is different, the classification exercise will entail important consequences. The term supplementary means of interpretation is defined only in part by VCLT Article 32 since, by its very terms, this provision covers "supplementary means of interpretation, including" — that is, but not necessarily limited to- "the preparatory work of the treaty and the circumstances of its conclusion" (emphasis added). By contrast, the term context is defined in VCLT Article 31(2) as follows:

The context for the purpose of the interpretation of a treaty shall comprise, in addition to the text, including its preamble and annexes:

(a) any agreement relating to the treaty which was made between all the parties in connection with the conclusion of the treaty;

(b) any instrument which was made by one or more parties in connection with the

${ }^{134}$ For example, VCLT Article 32 refers to supplementary means of interpretation, including preparatory work. We do not know what else is intended.

${ }^{135}$ Appellate Body Report, Korea-Definitive Safeguard Measure on Imports of Certain Dairy Products, para. 98, WT/DS98/AB/R (adopted Jan. 12, 2000).

${ }^{136}$ Appellate Body Report, Chile-Price Band System and Safeguard Measures Relating to Certain Agricultural Products, WT/DS207/AB/R \& corr.1 (adopted Oct. 23, 2002). 
conclusion of the treaty and accepted by the other parties as an instrument related to the treaty.

Both definitions refer to actions that occurred in the past: prior to, or at the conclusion of, the treaty. The supplementary means are in a vertical relationship with the final agreement: preparatory work is an input into the final product. By contrast, context points to a horizontal relationship. The immediate context of any particular provision in any given international agreement comprises the rest of the agreement and its preamble and annexes. The broader context for a provision can encompass self-standing instruments, insofar their subject matter relates to that of the primary treaty in question.

Just what should be understood as context for the WTO Agreement itself is not answered in the Agreement and is largely left to the adjudicator. The only legislative guidance is of a temporal nature: the context, however defined, must be in connection with the conclusion of the treaty. The work of the special rapporteur Waldock ${ }^{137}$ provides ample evidence that this temporal element-referring, in particular, to agreements signed when the treaty was being concluded-was fully intended. In the case of the WTO Agreement, we cannot, for example, regard as context any legal instruments that were signed after April 1994, when the Uruguay round package was signed at Marrakesh.

VCLT Article 31(2)(b) can be interpreted quite broadly: the reference to any instrument relating to the treaty could potentially include instruments that relate only remotely to the original contract. Notwithstanding its imprecision, that same provision seems to suggest that a critical determinant is the intent of the parties to see the original and the contextual agreements as part of a whole.

As to the role of non-WTO international law, there is wide disagreement. Although some authors, such as Pauwelyn, ${ }^{138}$ argue that non-W TO international law may be applicable in WTO dispute settlement, most commentators agree that non-WTO international law is relevant not as a source, but as interpretative element. For example, even authors such as Kuijper, ${ }^{139}$ who takes the view that the WTO regime is self-contained when it comes to state responsibility, or Trachtman, ${ }^{140}$ who believes that WTO adjudicators cannot apply non-W TO international law, adopt a more "liberal" attitude when it comes to seeing the relevance of public international law in the interpretation of the WTO Agreement. From a more social science-based perspective, Howse ${ }^{141}$ warns against the danger of interpreting the WTO Agreement in clinical isolation from the rest of public international law and thus of constructing it as an agreement with little connection to today's problems and concerns.

Table 1 provides a schematic account of how WTO adjudicating bodies have classified various interpretative elements. I then move to a critical discussion of the case law.

${ }^{137}$ Humphrey Waldock, Humphrey, Special Rapporteur, Second Report on the Law of Treaties, UN Doc. A/CN.4/156 (1963), reprinted in [1963] 2 Y.B. Int'l L. Comm'n 36.

138 PAUWELYN, supra note 72.

139 Pieter Kuijper, The Law of the GATT as a Special Field of International Law: Ignorance, Further Refinement or Self-Contained System of International Law? NETHERLANDS Y.B. INT'L L. 227.

${ }^{140}$ Trachtman, supra note 21; Trachtman, supra note 25.

${ }^{141}$ Robert Howse, The Appellate Body Rulings in the Shrimp/Turtle Case: A New Legal Baseline for the Trade and Environmental Debate, 27 COLUM. J. ENVTL. L. 491 (2002). 
TABLE 1.

CLASSIFICATION OF INTERPRETATIVE ELEMENTS BY WTO ADJUDICATING BODIES

\begin{tabular}{|c|c|c|c|c|c|c|c|c|c|}
\hline & $\begin{array}{l}\text { Ordinary } \\
\text { meaning of } \\
\text { the term }\end{array}$ & Context & $\begin{array}{c}\text { Object and } \\
\text { purpose of } \\
\text { treaty }\end{array}$ & $\begin{array}{l}\text { Subsequent } \\
\text { agreements }\end{array}$ & $\begin{array}{l}\text { Subsequent } \\
\text { practice }\end{array}$ & $\begin{array}{l}\text { Other } \\
\text { relevant rules of } \\
\text { international law }\end{array}$ & $\begin{array}{l}\text { Special } \\
\text { meaning }\end{array}$ & $\begin{array}{l}\text { Supple- } \\
\text { mentary } \\
\text { means }\end{array}$ & Other \\
\hline $\begin{array}{c}\text { Oxford English } \\
\text { Dictionary }\end{array}$ & $\mathrm{X}$ & & & & & & & & \\
\hline $\begin{array}{l}\text { Preambles in } \\
\quad \text { various covered } \\
\text { agreements }\end{array}$ & & & $\mathrm{X}$ & & & & & & \\
\hline $\begin{array}{l}\text { Negotiating } \\
\text { documents }\end{array}$ & & & & & & & & $\mathrm{X}$ & \\
\hline $\begin{array}{l}\text { Circumstances } \\
\text { surrounding } \\
\text { the conclusion } \\
\text { of the } \\
\text { agreement } \\
\text { (during } \\
\text { negotiations) }\end{array}$ & & & & & & & & $\mathrm{X}$ & \\
\hline $\begin{array}{l}\text { Common WTO } \\
\text { practice after } \\
1995\end{array}$ & & & & & $X$ & & & & \\
\hline $\begin{array}{l}\text { GATT panel } \\
\text { reports }\end{array}$ & & & & & & & & $\mathrm{X}$ & \\
\hline $\begin{array}{l}\text { WTO panel } \\
\text { reports }\end{array}$ & & & & & & & & $\mathrm{X}$ & \\
\hline $\begin{array}{l}\text { Acts by WTO } \\
\text { organs }\end{array}$ & & & & & & & & $\mathrm{X}$ & \\
\hline $\begin{array}{l}\text { International } \\
\text { agreements }\end{array}$ & & $\mathrm{X}$ & & & & $\mathrm{X}$ & & $\mathrm{X}$ & $\mathrm{X}$ \\
\hline $\begin{array}{l}\text { Acts by } \\
\text { international } \\
\text { organizations }\end{array}$ & & & & $\mathrm{X}$ & & & & $\mathrm{X}$ & \\
\hline $\begin{array}{l}\text { Decisions by } \\
\text { international } \\
\text { courts }\end{array}$ & & & & & & & & $\mathrm{X}$ & \\
\hline $\begin{array}{l}\text { Informal } \\
\text { agreements } \\
\text { between WTO } \\
\text { members }\end{array}$ & & & & & & & & $\mathrm{X}$ & \\
\hline $\begin{array}{l}\text { Decisions by } \\
\text { domestic courts }\end{array}$ & & & & & & & & $\mathrm{X}$ & \\
\hline $\begin{array}{l}\text { Unilateral } \\
\text { declarations }\end{array}$ & & & & & & & & & $\mathrm{X}$ \\
\hline Doctrine & & & & & & & & $\mathrm{X}$ & \\
\hline
\end{tabular}

The Text

As already mentioned above, WTO adjudicating bodies have made extensive use of the Oxford English Dictionary (as well as other dictionaries) in order to interpret the WTO Agreement and its annexes.

\section{The Context}

The panel report in EC-Chicken Cuts $^{142}$ addressed a dispute between the EC and Brazil concerning the proper tariff classification of salted meat under the Harmonized System (HS) treaty. ${ }^{143}$ To do that, the panel first had to pronounce on the legal relevance of the HS. The

${ }^{142}$ Panel Report, EC-Chicken Cuts, supra note 133, paras. 7.190-.241; Appellate Body Report, EC-Chicken Cuts, supra note 133, para. 199.

${ }^{143}$ International Convention on the Harmonized Commodity Description and Coding System, June 14, 1983, 1035 UNTS 3. 
HS treaty, which provides a classification for all goods traded internationally, binds several WTO members that have formally ratified it and de facto is observed by other WTO members, when scheduling their commitments: although it is not explicitly referred to in the GATT, parties routinely have recourse to it is during negotiations. It has been referred to in many disputes involving tariff-classification issues but, except for a cryptic statement by the $\mathrm{AB}$ in EC-Computer Equipment ${ }^{144}$ to the effect that interpretation of schedules should be in line with the HS, WTO adjudicating bodies had not clarified its status prior to $E C$-Chicken Cuts. That panel held that in the sense of VCLT Article 31(2), the HS treaty is part of the context for the GATT. Based on this conclusion, the panel examined in detail the HS rules of interpretation. The approach of the EC-Chicken Cuts panel was eventually confirmed by the AB. At the moment of writing, the HS treaty is the only item of international law that has been found to be context for the WTO Agreement. ${ }^{145}$

\section{Object and Purpose}

WTO adjudicating bodies have correctly referred to the object and purpose of the treaty as a whole, not of its specific provisions: various reports ${ }^{146}$ mention the GATT's preamble or its annexes as providing an authentic description of the object and purpose of the instrument that they are interpreting. They have abstained from teleological interpretations, however, which inherently carry the risk of violating DSU Article 3.2 (the balance of rights and obligations) since in international relations, sovereigns agree both on common ends and on the means to pursue them. Interpreting the former without taking account of the latter could violate the clauses of the contractual arrangement.

\section{Subsequent Agreement}

The panel report in Mexico-Telecoms ${ }^{147}$ relied heavily on a series of regulations and recommendations by the International Telecommunications Union (ITU) to clarify its understanding of accounting rates. In support of its decision to move and discuss various ITU instruments, the panel noted the following: the ITU regulations are instruments binding both Mexico and the United States; the ITU recommendations are relevant since the parties to the dispute, as well many other WTO members, are members of the ITU. Essentially, without explicitly saying so, this panel suggested that it was treating the ITU regulations and recommendations as something akin to subsequent agreement in the sense of VCLT Article 31(3).

Irrespective of the merits of this approach, it is imperative to ask whether Mexico-Telecoms can be considered representative. There are good reasons to answer this question in the negative: first, it is only a panel report; second, the $\mathrm{AB}$, when confronted with a more or less similar situation, preferred to use multilateral agreements concluded outside the WTO as involving

${ }^{144}$ Appellate Body Report, EC-Customs Classification of Certain Computer Equipment, para. 89, WT/DS62/AB/R, WT/DS67/AB/R, WT/DS68/AB/R (adopted June 22, 1998) [hereinafter EC-Computer Equipment].

${ }^{145}$ On the issue of interpretation of schedules, see Isabelle Van Damme, The Interpretation of Schedules of Commitments, $41 \mathrm{~J}$. WORLD TRADE 1 (2007).

${ }^{146}$ See, for example, the AB report in EC-Chicken Cuts, supra note 133, paras. 236-38.

${ }^{147}$ Panel Report, Mexico-Telecoms, supra note 32, paras. 7.129-.136. 
factual issues only — and not, that is, as providing supplementary means of interpretation. All this leads me to conclude that Mexico-Telecoms is a highly atypical case on this particular issue.

\section{Subsequent Practice}

The most recent WTO case law seems to have adopted the view that only unanimous practice by all WTO members could qualify as subsequent practice. This approach amounts to introducing an exceedingly restrictive filter in the sense that few, if any, practices are unanimous and could thus qualify as subsequent practice in conformity with VCLT Article 31(3).

The AB first found, in Japan-Alcoholic Beverages $I I^{148}$ that subsequent practice within the meaning of Article 31(3)(b) entails a "'concordant, common and consistent' sequence of acts or pronouncements which is sufficient to establish a discernable pattern implying the agreement of the parties [to a treaty] regarding its interpretation." In U.S. - Gambling, ${ }^{149}$ the AB clarified that establishing subsequent practice within the meaning of Article 31(3)(b) involved two elements: "(i) there must be a common, consistent, discernible pattern of acts or pronouncements; and (ii) those acts or pronouncements must imply agreement on the interpretation of the relevant provision." In EC-Computer Equipment, ${ }^{150}$ the AB went so far as to state that classification decisions by the HS Committee could be considered subsequent practice. Then, in EC_Chicken Cuts $^{151}$ the panel held that practice by one WTO member alone can qualify as subsequent practice-in the VCLT sense of the term — if it is the only relevant practice. In the case at hand, the EC was the only importing WTO member with any practice of classifying the products in question (salted chicken cuts). In light of this factual observation, the panel accepted such evidence as subsequent practice in accordance with VCLT Article 31(3). We should recall that under VCLT Article 31(3), adjudicating bodies must take into account relevant subsequent practice.

On appeal, the $\mathrm{AB}$ half-closed the door to this understanding of the term subsequentpractice. It held that a few WTO members (but not only one) might establish subsequent practice-if only a few have traded in a particular commodity. The $\mathrm{AB}$ rejected the view, however, that reliance on practice by just one member is relevant to establishing subsequent practice in the VCLT sense of the term:

We share the Panel's view that not each and every party must have engaged in a particular practice for it to qualify as a "common" and "concordant" practice. Nevertheless, practice by some, but not all parties is obviously not of the same order as practice by only one, or very few parties. To our mind, it would be difficult to establish a "concordant, common and discernible pattern" on the basis of acts or pronouncements of one, or very few parties to a multilateral treaty, such as the WTO Agreement. We acknowledge, however, that, if only some WTO Members have actually traded or classified products under a given heading, this circumstance may reduce the availability of such "acts and pronouncements"

${ }^{148}$ Appellate Body Report, Japan-Taxes on Alcoholic Beverages, at 12, WT/DS8/AB/R, W T/DS10/AB/R, WT/DS11/AB/R (adopted Nov. 1, 1996), modifying Panel Report, Japan-Taxes on Alcoholic Beverages, W T/DS8/R, W T/DS10/R, WT/DS11/R (adopted Nov. 1, 1996) [hereinafter Japan-Alcoholic Beverages II].

${ }^{149}$ Appellate Body Report, U.S.-Gambling, supra note 128, para. 192.

${ }^{150}$ Appellate Body Report, EC—Computer Equipment, supra note 144, para. 90.

${ }^{151}$ Panel Report, EC-Chicken Cuts, supra note 133, para. 7.289. 
for purposes of determining the existence of "subsequent practice" within the meaning of Article 31(3)(b). ${ }^{152}$

Commenting on the AB Report in EC-Computer Equipment, the AB in EC-Chicken Cuts noted:

The Appellate Body made these statements in the context of an interpretation pursuant to Article 32 of the Vienna Convention, but, as the Panel put it, these statements "confirm[] the importance of the classification practice of the importing Member whose schedule is being interpreted [but] also indicate[] that the classification practice of other WTO Members, including the exporting Member's practice, may be relevant." In our view, these statements cannot be read to justify exclusive reliance on the importing Member's classification practice. Therefore, we fail to see how the Panel's finding that it was "reasonable to rely upon EC classification practice alone in determining whether or not there is 'subsequent practice' that 'establishes the agreement' of WTO Members within the meaning of Article $31(3)(b)$ " can be reconciled with these statements of the Appellate Body in EC-Computer Equipment. ${ }^{153}$

\section{Other Relevant Rules of Public International Law}

The AB in its report in EC-Chicken Cuts held that the HS treaty could possibly qualify as an "other relevant rule of public international law" under VCLT Article 31(3)(c). Since the $\mathrm{AB}$ 's discussion is rather cryptic, however, it is probably wise not to see too much in it. ${ }^{154}$

\section{Special Meaning}

The panel in its report in Mexico-Telecoms ${ }^{155}$ discussed at length whether the term interconnection appearing in the Telecoms Reference Paper had been given a special meaning by the WTO negotiators, only to conclude that it had not. In arriving at this conclusion, however, the panel neglected to review carefully all the relevant negotiating documents. Indeed, some of them, such as the Memorandum on Accounting Rates, ${ }^{156}$ could have led the panel to conclude that the term interconnection was meant to cover only mode 3-that is, cases where an investor establishes commercial presence in a foreign country and supplies services from its premises.

\section{Supplementary Means}

Supplementary means is the most extensive category of interpretive elements classified as such by WTO adjudicating bodies. Recall that by virtue of VCLT Article 32 (emphasis added, below), a judge has substantial discretion to shape the list of supplementary means:

${ }^{152}$ Appellate Body Report, EC—Chicken Cuts, supra note 133, para. 259.

${ }^{153}$ Id., para. 266.

${ }^{154}$ Id., paras. 195-200. Moreover, as argued above, the HS has been acknowledged as legal context for the WTO Agreement anyway.

${ }^{155}$ Panel Report, Mexico-Telecoms, supra note 32, paras. 7.108-.117.

156 This memorandum is an understanding reached at the end of the negotiations and reflected in paragraph 7 of the Report of the Group on Basic Telecommunications, W TO doc. S/GBT/4 (Feb. 15, 1997). The understanding was later confirmed (taken note of) by the Council for Trade in Services, in paragraph 8 of the Report to the General Council on Activities During 1997, W TO Doc. S/C/5 (Nov. 28, 1997). 
Recourse may be had to supplementary means of interpretation, including the preparatory work of the treaty and the circumstances of its conclusion, in order to confirm the meaning resulting from the application of article 31 , or to determine the meaning when the interpretation according to article 31:

(a) leaves the meaning ambiguous or obscure; or

(b) leads to a result which is manifestly absurd or unreasonable.

The most frequently used supplementary means is the travaux préparatoires of the WTO Agreement and its annexes.

Travaux préparatoires of the WTO Agreement. As already discussed, the term may in VCLT Article 32 makes it clear that recourse to supplementary means is not a matter of legal compulsion: the judge has substantial discretion on this score. There are many good reasons arguing against recourse: not everyone participates in negotiations; the negotiating history often points to no concrete outcome; or a provision might have acquired a whole new meaning over the years. There are also good arguments, however, in favor of recourse: negotiations are evidence of the will of the principals (the framers) and thus help circumscribe the mandate of the agents (adjudicating bodies): recourse to the negotiating history helps to ensure that by the end of the interpretative exercise, WTO adjudicating bodies will have respected their mandate, under DSU Article 3.2, not to undo the balance of rights and obligations as struck by the framers. Since arguments can be made both in favor and against recourse to the preparatory work, the drafters of VCLT thought it sensible to leave it to adjudicating bodies to decide when such recourse should be made.

What VCLT Article 32 does specify is how such supplementary means are to be used: recourse to them is appropriate in order either to confirm a conclusion reached or to determine the meaning if that remains uncertain after the interpretative elements included in VCLT Article 31 have been exhausted. Obviously, it is the latter use that enhances the value and relevance of travaux préparatoires.

The customary nature of VCLT Article 32. In an effort to eliminate doubts ${ }^{157}$ regarding the status of VCLT Article 32 in public international law, the AB held in Japan-Alcoholic Beverages $I I^{158}$ that there can be no doubt that Article 32 of the Vienna Convention, dealing with the role of supplementary means of interpretation, has attained the status of a rule of customary international law.

Conditions for recourse to travaux préparatoires in practice. WTO adjudicating bodies have had recourse to VCLT Article 32 for various reasons: (1) Sometimes, when it would be helpful in order to confirm an interpretation reached, (2) always, in order to clarify the meaning of a term left obscure after the interpretative elements in VCLT Article 32 have been exhausted, and (3) very rarely, before exhausting those elements.

The picture emerging from an examination of the WTO case law demonstrates the overall tendency of adjudicating bodies to use travaux préparatoires as a means of supporting conclusions that they have already reached. On fewer occasions, recourse to travaux préparatoires was made because the meaning of a provision was thought to be obscure: in all such cases, however,

${ }^{157}$ Although in United States - Gasoline, supra note 111, the AB had already clarified that the VCLT system codifies the customary rules of interpretation, through this ruling in Japan-Alcoholic Beverages II, supra note 148, it makes clear that its prior ruling covers not only VCLT Article 31, but also Article 32.

${ }^{158}$ Appellate Body Report, Japan-Alcoholic Beverages II, supra note 148, at 97. 
it is through recourse to the travaux préparatoires that the adjudicating bodies sought clarifications.. The panel reports in India-Quantitative Restrictions ${ }^{159}$ and Canada-Pharmaceutical Patents ${ }^{160}$ are representative of cases where recourse to travaux préparatoires was made in order to confirm an interpretation already reached under VCLT Article 31. The AB has occasionally made use of this potential resource in a more nuanced manner: U.S.-Upland Cot$\operatorname{ton}^{161}$ suggests, though without taking an explicit position, that recourse to the preparatory work was not necessary in order to decide whether export credits were a form of export subsidy covered by the WTO Agreement on Agriculture. Nevertheless, it proceeded to examine some preparatory work and confirmed its initial view. ${ }^{162}$

Recourse to travaux préparatoires in order to determine a provision's meaning — as opposed to clarifying a meaning left obscure after making recourse to VCLT Article 31-is rare. In Canada-Pharmaceutical Patents ${ }^{163}$ the panel, when called to interpret the term limited exceptions figuring in TRIPS Article 30, moved directly to the preparatory work of TRIPS Article 30 instead of examining the term in accordance with the sequence specified in the VCLT. By the same token, in Korea-Procurement, ${ }^{164}$ before having recourse to the process defined in VCLT Article 31, the panel moved directly to the negotiating history of Korea's accession to the WTO Agreement on Government Procurement in order to satisfy itself as to the actual extent of the obligations assumed by Korea. In Canada_Dairy, ${ }^{165}$ after holding that a notation in Canada's schedule of commitment was not clear on its face (as being general and ambiguous), the AB moved to the preparatory work in order to clarify the scope of Canada's engagement and only thereafter considered the sources identified in VCLT Article 31. Cases such as the above should be only as outliers, however; in the overwhelming majority of the cases, WTO adjudicating bodies have first tried to exhaust the references of VCLT Article 31 before moving to Article $32 .{ }^{166}$ A recent, representative example is U.S._-Gambling, ${ }^{167}$ where the $\mathrm{AB}$ decided that

159 Panel Report, India-Quantitative Restrictions on Imports of Agricultural, Textile and Industrial Products, para. 5.110, WT/DS90/R (adopted Sept. 22, 1999); Appellate Body Report, India-Quantitative Restrictions on Imports of Agricultural, Textile and Industrial Products, WT/DS90/AB/R (adopted Sept. 22, 1999).

160 Panel Report, Canada_Pharmaceutical Products, supra note 36, para. 7.47.

${ }^{161}$ Appellate Body Report, United States-Subsidies on Upland Cotton, WT/DS267/AB/R, paras. 623-27 (adopted Mar. 21, 2005) (reported by Richard H. Steinberg at 99 AJIL 852 (2005)) [hereinafter U.S.-U Upland Cotton].

${ }^{162}$ Interestingly, in a separate opinion (at paragraphs 631-41), one member of the AB checking the same negotiating history reached the opposite conclusion-namely, that export credits are not covered by the existing disciplines. It should be noted, however, that even this member of the AB falls short of stating that recourse to preparatory work was strictly necessary under the circumstances.

163 Panel Report, Canada-Pharmaceutical Patents, supra note 36, para. 7.29.

${ }_{164}$ Panel Report, Korea-Procurement, supra note 69, paras. 7.74-83.

165 Appellate Body Report, Canada-Measures Affecting the Importation of Milk and the Exportation of Dairy Products, para. 138, WT/DS103/AB/R, WT/DS113/AB/R (adopted Oct. 27, 1999) [hereinafter CanadaDairy].

${ }^{166}$ Nevertheless, one cannot help thinking whether, and to what extent, the VCLT is the best tool for discussing the scope of contractual elements. Some of its elements (such as text, context) seem appropriate, whereas others (such as relevant rules of public international law) seem far less so. Technically, all schedules of concessions are annexes to the WTO Agreement and are therefore, by virtue of DSU Article 3.2, subject to interpretation through the VCLT. A strong argument can be made, however, in support of the contrary position. When trading partners make a promise to each other, they are laying out the foundation on which a treaty will eventually be founded and not the other way round. The VCLT is probably the last thing that negotiators have in mind when exchanging concessions.

It seems that in this particular context, evidence sought through what is called "circumstances surrounding the conclusion of a negotiation" in VCLT Article 32 should probably take precedence over any other interpretative 
recourse to the circumstances surrounding the negotiation of GATS was necessary for it to clarify the scope of the U.S. commitment with respect to cross-border supply of betting and gambling services; in the AB's view, the scope of that commitment remained unclear following exhaustion of the interpretative elements included in VCLT Article 31. Note the difference in the two AB reports: Canada-Dairy moves to VCLT Article 32 without any reference to the elements of Article 31, whereas U.S._Gambling does the exact opposite. The latter is later in time and for this reason alone, it can be taken as better reflecting the AB's current approach.

Negotiating documents. GATT/W TO negotiations are usually divided among various negotiating groups, each with a specific mandate. It is common for negotiators to ask the chairman of a negotiating group to sum up in a paper the picture emerging from group discussions at a certain stage. Such documents help reveal the extent of agreement and the extent of disagreement among parties - without, however, reflecting a legally binding agreement. During the proceedings that led to the panel report in U.S. - Softwood Lumber III, ${ }^{168}$ the panel was requested to provide an opinion on the legal relevance of discussion papers that were exchanged during negotiations. The panel decided that such papers were of no probative value.

We note that the text of the SCM Agreement does not in any way provide an exception for the right to exploit natural resources. The only exception from the term "goods or services" provided for in Article 1.1(a)(1)(iii) SCM Agreement is general infrastructure, not natural resources. Moreover, the paper referred to by Canada in support of its argument that harvesting rights are not covered by Article 1.1(a)(1)(iii) SCM Agreement, called Discussion Paper No. 6, is an "informal discussion paper" from the Chairman of the Negotiating Group on Subsidies and Countervailing Measures dated 4 September 1990, which together with six other "informal discussion papers" was circulated in preparation for the issuance of a revised version of the Chairman's draft text of the SCM Agreement. Canada argues that this Discussion Paper reflects an understanding at the time of the SCM Agreement negotiations of the fundamental difference between tangible commercial inputs and intangible real property rights. We note however that, as stated in the Chairman's Note accompanying the discussion paper, this paper was circulated solely to "facilitate" discussions and that it did not reflect the Chairman's view of "what may be included in the subsequent revision", nor did it "have any status relating [it] to the Chairman's paper." The Note further states that some of the views expressed in the discussion papers "are purposefully provocative in order to make evident technical complexities and/or workability (or its lack) of certain approaches." In our view, this Discussion Paper thus has little if any probative value, especially in light of the fact that the reference to "harvesting rights" as separate from "goods" was not included in the final text of the Agreement.

In U.S.-Carbon Steel ${ }^{169}$ the AB clarified that absence of probative value does not mean that such documents should be regarded as totally irrelevant. Indeed, in its view, a chairman's note

elements. Unfortunately, the recent case law of the AB, when called to interpret the scope of commitments, leaves much to be desired in terms of faithfully reproducing the balance of rights and obligations as struck by the negotiating partners. See, for example, the Appellate Body reports in U.S.-Upland Cotton, supra note 161, EC-Export Subsidies on Sugar, supra note 95, and U.S._Gambling, supra note 128, as well as the panel report in Mexico-Telecoms, supra note 32.

167 Appellate Body Report, U.S._-Gambling, supra note 128, paras. 197-212.

168 Panel Report, United States_-Preliminary Determinations with Respect to Certain Softwood Lumber from Canada, para. 7.26, WT/DS236/R (adopted Nov. 1, 2002) (reported by Chi Carmody at 100 AJIL 664 (2006)).

${ }^{169}$ Appellate Body Report, United States-Countervailing Duties on Certain Corrosion-Resistant Carbon Steel Flat Products from Germany, para. 90 n.83, WT/DS213/AB/R \& corr.1 (adopted Dec. 19, 2002). 
could serve as indication as to what has been discussed among negotiators. This report thus reveals the AB's willingness to examine notes prepared by negotiating group chairmen that summarize the group's discussions in order to see whether a particular issue was actually raised during negotiations. Without explicitly saying so, the AB seemed willing to treat such documents as supplementary means of interpretation.

Recall our discussion about the legal significance of the HS treaty. That document is not the only one that can be used in order to schedule concessions. There are other, informal agreements that are often negotiated among the trading partners that serve the same function. They are not, however, elevated to the status of context. One could hypothesize that in the eyes of WTO adjudicating bodies, the form of a document influences its classification and therefore how it is used. In this vein, the HS treaty was most likely acknowledged as context because it is an international treaty, whereas other informal documents serving a similar function have been either used as supplementary means or reduced to irrelevance. The Modalities Paper, ${ }^{170}$ for example, reflected an agreement among negotiators during the Uruguay round with regard to the schedules of commitments in the farm trade. The $\mathrm{AB}$ on two occasions dismissed ${ }^{171}$ the interpretative relevance of the Modalities Paper altogether. In EC-Bananas $I I I^{172}$ the AB held that the Modalities Paper is not explicitly referenced in the WTO Agreement on Agriculture, and it implied that the paper could, at best, serve as a supplementary means of interpretation. Then, in EC_Export Subsidies on Sugar, ${ }^{173}$ the AB categorically held that the Modalities Paper did not constitute an agreement among parties (which is a point beside the point) and decided to ignore it altogether. ${ }^{174}$ In the GATS context, informal papers have been accorded the status of supplementary means. The panel report in Mexico-Telecoms ${ }^{175}$ discussed, inter alia, the relevance of GATT/WTO secretariat notes prepared at the request of the negotiating parties during a trade round (in the case at hand, the Uruguay Round). This panel was examining the relevance of the Scheduling of Initial Commitments in Trade in Services: Explanatory Note, a document prepared by the secretariat and later adopted by the GATS Council, the ratione materiae competent body to decide on the adoption of such documents). The aim of the document, now widely know as the Scheduling Guidelines, was to help prospective WTO members in scheduling their commitments in the services sector. These guidelines are the equivalent for the GATS to the HS treaty for the GATT - except that, in contrast to the HS treaty, Scheduling Guidelines was formally a decision of the GATS Council and not an international treaty to which sovereigns can adhere. The panel decided to use the guidelines as supplementary means:

7.43. Additional evidence, for the view that cross-border supply does not imply the presence of the service supplier in the market into which the service is delivered, is contained

170 Modalities for the Establishment of Specific Binding Commitments Under the Reform Programme, GATT Doc. MTN.GNG/MA/W/24 (Dec. 20, 1993).

${ }^{171}$ Nevertheless, reading carefully paragraphs 138 to 157 of the AB's report in Canada-Dairy, supra note 165, one may well be left with the impression that AB took the Modalities Paper into account on the way to its finding about the ambit of Canada's commitment.

${ }^{172}$ Appellate Body Report, EC-Bananas III, supra note 43, para.157.

${ }^{173}$ Appellate Body Report, EC-Export Subsidies on Sugar, supra note 95, para. 199.

${ }_{174}$ The central question, of course, was whether the Modalities Paper could have served as supplementary means of interpretation.

${ }^{175}$ Panel Report, Mexico-Telecoms, supra note 32, paras. 7.43-.44. 
in a document entitled "Scheduling of Initial Commitments in Trade in Services: Explanatory Note" (the "Explanatory Note"), issued by the GATT Secretariat as a working document for the Group of Negotiations on Services. The Explanatory Note states that the supply of a service through telecommunications is an example of cross-border supply "since the service supplier is not present within the territory of the Member where the service is delivered" (emphasis added). We accord substantial interpretative weight to this statement. The Explanatory Note was requested by the Group of Negotiations on Services, and issued in September 1993, during a period of intense drafting of initial commitments to meet the deadline for the completion of schedules in December of that year. During and after that period, the Explanatory Note was heavily relied upon by negotiators to interpret their own and other negotiators' commitments. The Explanatory Note was revised somewhat in 2001—without however modifying the statement with respect to the presence of cross border suppliers — and was adopted by the Council on Trade in Services as "Guidelines for the scheduling of specific commitments under the General Agreement on Trade in Services (GATS)" (the "Scheduling Guidelines"). Even though the Explanatory Note and the Scheduling Guidelines each state that they cannot be considered as "authoritative" or "legal" interpretations of the GATS, we find that the source, content, and use by negotiators of the Explanatory Note, together with its later adoption by Members as the Scheduling Guidelines, provides an important element with which to interpret the provisions of the GATS.

7.44. In interpreting the scope of cross border supply in Article I:2(a) of the GATS, we need not decide whether the Explanatory Note provides "context" (as an agreement or instrument made in connection with the conclusion of the GATS) under paragraph 2 of Article 31 of the Vienna Convention, or whether it can be "taken into account", together with the context, as a subsequent agreement or practice under paragraph 3 of the same provision. In any case, we consider that the source, content and use of the Explanatory Note make it part of the "circumstances" of the conclusion of the GATS, within the meaning of Article 32 of the Vienna Convention. We may therefore properly have recourse to the Explanatory Note to confirm our understanding of the ordinary meaning of Article I:2(a) of the GATS.

This finding was echoed in U.S._-Gambling, ${ }^{176}$ where the AB held the Scheduling Guidelines (the document discussed in Mexico_-Telecoms) to be part of the travaux préparatoires, as the latter are defined in VCLT Article 32. The AB, in U.S._-Gambling, paid particular attention to the fact that WTO members based their commitments on the Scheduling Guidelines. Note, however, the contrast between this approach and that taken in EC-Export Subsidies on Sug$a r .{ }^{177}$ In that case the $\mathrm{AB}$ noted the absence of any reference to the Modalities Paper in the WTO Agreement on Agriculture-without even asking whether there are schedules in use that have been based on the paper's scheduling guidelines. The mere lack of a mention in the Agreement on Agriculture was considered adequate to determine the matter. The rationale for accepting the Scheduling Guidelines as supplementary means and rejecting the Modalities Paper is thus not the same. Again, form seems to be the distinguishing feature (although not explicitly relied upon by the AB): the Modalities Paper is a document prepared by the WTO secretariat and circulated through the chairman of the negotiating group on Agriculture; though it has an

${ }^{176}$ Appellate Body Report, U.S.—Gambling, supra note 128, paras. 196, 204.

${ }^{177}$ Appellate Body Report, EC—Export Subsidies on Sugar, supra note 95, para. 199. 
official document number (MTN.GNG/MA/W/24), it is not a decision by a WTO organ. By contrast, the GATS Council formally adopted the Scheduling Guidelines.

Informal agreements among WTO members. In EC_Poultry, ${ }^{178}$ the panel faced the question whether, as Brazil argued, the bilateral Oilseeds Agreement" that it had concluded with the EC was relevant to the dispute. Noting that the Oilseeds Agreement had been negotiated within the framework of GATT Article XXVIII, and citing the Canada/EC - Wheat arbitration, the panel decided to consider that Agreement "to the extent relevant to the determination of the EC's obligations under the WTO agreements vis-à-vis Brazil." On appeal, the AB found that "no reversible error in the Panel's treatment" of the Oilseeds Agreement. The AB recognized that the Agreement was negotiated within the framework of GATT Article XXVIII and that it provided the basis for the tariff-rate quota that was at issue in the dispute. Accordingly, the AB stated that "the Oilseeds Agreement may serve as a supplementary means of interpretation."

Even assuming that an agreement has been proven, not every bilateral agreement will be accorded the status of supplementary means by WTO adjudicating bodies. Evidence of a bilateral agreement is a necessary, but not sufficient, condition: such an agreement must also be in close connection with the covered agreements. This question arose first in the GATT years, in a dispute between Canada and the EC. In connection with negotiations in the early 1960s concerning Canada's exports of wheat to the EC under the common agricultural policy, the parties entered into an agreement that would have extended the time limits within which Canada could challenge the EC's treatment of its wheat exports under GATT Article XXVIII. In ECArticle XXVIII, ${ }^{179}$ the EC challenged, before the arbitrator, Canada's right to bring a claim based on a bilateral agreement under the multilateral procedures of GATT. The arbitrator disagreed:

In principle a claim based on a bilateral agreement cannot be brought under the multilateral dispute settlement procedures of the GATT. An exception is warranted in this case given the close connection of this particular bilateral agreement with the GATT, the fact that the Agreement is consistent with the objectives of the GATT, and that both parties joined in requesting recourse to the GATT Arbitration procedures.

Close connection between the subject matter of a bilateral agreement and the WTO Agreement emerged as the criterion for deciding whether a bilateral agreement would be taken into account by a WTO adjudicating body. A case of close connection appears in the panel report in EC-Poultry mentioned above. ${ }^{180}$ The requirement for close connection should thus be understood as akin to the historical context as understood under VCLT Article 31(2).

There was no such close connection found in EC-Commercial Vessels, ${ }^{181}$ where the panel dealt with a bilateral agreement between Korea and the EC (called Agreed Minutes) whereby the parties undertook commitments as to their shipyard sector. In the EC's view, the reason for permitting (as an exception) the subsidization of its own shipyard sector was that doing so was a response to Korea's inability to implement the Agreed Minutes (and cut down its own

178 Panel Report, EC-Measures Affecting Importation of Certain Poultry Products, para. 202, WT/DS69/R (adopted July 23, 1998), modified by Appellate Body Report, EC-Measures Affecting Importation of Certain Poultry Products, paras. 83-85, WT/DS69/AB/R (adopted July 23, 1998).

179 Canada/European Communities Article XXVIII Rights, GATT B.I.S.D. (37th Supp.) at 80, 84 (1990).

180 See supra note 178 and accompanying text.

${ }^{181}$ Panel Report, EC-Measures Affecting Trade in Commercial Vessels, paras. 7.130-.132, W T/DS301/R (adopted June 20, 2005). 
subsidization, accordingly). Although the panel noted that the bilateral agreement was not a covered agreement, it did use that agreement to clarify the factual aspects of the dispute while. The panel did not use the agreement, however, as a legal ground for justifying the EC position.

When accepted as legally relevant, such agreements have been treated (explicitly in EC-Poultry, implicitly in other cases) as supplementary means of interpretation. As a consequence, recourse to them is not guaranteed. Absent such recourse, however, the WTO adjudicating body might be missing out on crucial factual elements that may help it to resolve the dispute. Future panels will be well advised to treat such agreements as part of the historical context, as per VCLT Article 31(2), assuming that there is no dispute as to their scope.

Circumstances surrounding the conclusion of the WTO Agreement. There are very few instances in which WTO adjudicating bodies have taken into account the circumstances surrounding of the WTO Agreement. One was Canada-Dairy, ${ }^{182}$ which was a peculiar case but worth mentioning anyway. In that case, as briefly discussed above, the $\mathrm{AB}$ first reached the conclusion that Canada's schedule was not clear on the issue of whether the concession entered by Canada was meant to be continuation of past practice, as Canada had asserted. The AB consequently decided to check the negotiating history of the concession. When moving there, the $\mathrm{AB}$ first observed that, contrary to what had been the case with the EC-Brazil Oilseeds Agreement, there was no bilateral agreement between Canada and the United States (the parties in dispute). The absence of such an agreement did not, however, stop the $\mathrm{AB}$ from moving on to examine the circumstances surrounding the conclusion of the WTO Agreement. But instead of checking the negotiating record, the $\mathrm{AB}$ referred to positions taken by the parties to the dispute during the WTO panel proceedings to substantiate its view that the Canada's commitment was meant to be a continuation of past practice and not a commitment on minimum access opportunities (which would have led to important practical ramifications). In the panel's view, noncontradicted statements made during the negotiation of the concession by the Canadian representative amounted to a tacit agreement between the parties in dispute. It is probably wise to treat this report as an outlier. ${ }^{183}$ It is the only instance where the $\mathrm{AB}$ accepted a tacit agreement—assuming one existed (and the United States claimed that it did not) — as a circumstance surrounding the negotiation of the WTO Agreement. Moreover, in a subsequent case, EC-Poultry (discussed above), the AB took a much tougher stance. In that case, a bilateral agreement was in place, and the defendant (the EC) did not question either its existence or its relevance. While taking note of this absence of objection by the EC, the AB still looked for extra assurances that the agreement existed and that the parties concurred as to its existence. It did not look for such extra assurances in Canada-Dairy.

In EC-Computer Equipment, ${ }^{184}$ the $\mathrm{AB}$ held that the classification practice of the EC (the defendant in this case) was part of the circumstances surrounding the conclusion of the WTO Agreement. In the case at hand, the dispute between the United States and the defendant concerned the latter's tariff treatment of some computer equipment. The $\mathrm{AB}$, in order to clarify

\footnotetext{
${ }^{182}$ Appellate Body Report, Canada-Dairy, supra note 165, para. 139.

183 The AB has never shown such a spirit to accommodate contractual promises in subsequent case law. Moreover, as indicated above, it is highly debatable (if not wrong altogether) that a promise was actually given. The United States contested, and the $\mathrm{AB}$ effectively accepted their position, that no agreement between the two partners was ever concluded. Moreover, although the AB stated that it would look at the circumstances surrounding the negotiations, its examination was limited to the submissions to the panel (over ten years later).

${ }^{184}$ Appellate Body Report, EC_Computer Equipment, supra note 144, paras. 92, 95.
} 
the EC's commitment, moved to VCLT Article 32. In the AB's view, for prior (to the entry into force of the WTO Agreement) customs classification to be relevant it must be consistent; "[i] nconsistent classification practice . . cannot be relevant in interpreting the meaning of a tariff concession."

Domestic court decisions issued at the time of negotiation. The panel report in EC-Chicken Cuts $^{185}$ took the view that domestic court decisions could be regarded as supplementary means of interpretation in accordance with VCLT Article 32. In the case at hand, as already discussed above, Brazil challenged the EC's unilateral decision to change the tariff treatment of salted chicken cuts after the WTO Agreement was concluded. In Brazil's view, the defendant's decision violated the treaty and nullified its interests since the decision subjected chicken cuts to a higher tariff regime. In defense, the EC argued, inter alia, that EC court decisions before the entry into force of the WTO Agreement made it clear that salted chicken cuts had consistently been subjected to the more burdensome of the potential tariff categories. Although it eventually rejected the EC's substantive position, the panel accepted the relevance of such decisions and reviewed them under the auspices of VCLT Article 32. On appeal, the AB confirmed the panel's understanding on this issue, adding that judgments will have less relevance than, for example, legislative acts, since they are, by definition, transaction-specific.

GATT panel reports. Recall that Article XVI:1 of the WTO Agreement reads:

Except as otherwise provided under this Agreement or the Multilateral Trade Agreements, the WTO shall be guided by the decisions, procedures and customary practices followed by the CONTRACTING PARTIES to GATT 1947 and the bodies established in the framework of GATT 1947.

This clause is the institutional acknowledgement of the relevance of an (unidentified) series of GATT documents. Case law has clarified that GATT panel reports come under the ambit of this provision. In VCLT parlance, GATT reports have been used as supplementary means. In practice, however, their importance has sometimes been more substantive than mere guidance. During the GATT years, panel reports would not be adopted at the mere request of the winning party. Panel reports were adopted by consensus. Practice reveals that in the majority of the cases, reports were adopted through decisions by the GATT contracting parties. Some reports were never adopted, however, and their legal relevance was therefore questionable. In WTO practice, adjudicating bodies have referred not only to GATT adopted reports, but also, on occasion, to unadopted reports - when they agreed with the legal reasoning reflected therein-in order to confirm their understanding of an issue.

The question whether adopted GATT panel reports represent decisions of the contracting parties to GATT 1947 — and whether they thus formed, by virtue of Article 1(b)(iv) of GATT $1994,{ }^{186}$ an integral part of the GATT — arose in Japan-Alcoholic Beverages II. ${ }^{187}$ The panel held that adopted reports are an integral part of GATT 1994 since they are "other decisions of the CONTRACTING PARTIES to GATT 1947” within the meaning of Article 1(b)(iv)

\footnotetext{
185 Panel Report, EC_Chicken Cuts, supra note 133, para. 7.392; Appellate Body Report, supra note 133, paras. $310-45$.

${ }^{186}$ According to this provision, decisions by the GATT contracting parties are part of the GATT 1994, the legal instrument that succeeded GATT 1947 (the original GATT).

${ }^{187}$ Panel Report, Japan-Alcoholic Beverages II, supra note 148, para. 6.10; Appellate Body Report, JapanAlcoholic Beverages II, supra note 148, at 15.
} 
of GATT 1994. The AB disagreed, holding that a decision to adopt a panel report is not a decision within the meaning of Article 1(b)(iv) of GATT 1994. In its view, adopted reports are, instead, "an important part of the GATT acquis" (page 15).

The term GATT acquis was an invention of the $\mathrm{AB}$ and not detailed any further in JapanAlcoholic Beverages II. Following some months in limbo as to the precise meaning of the term GATT acquis, the issue arose again in the panel report in U.S._FSC. ${ }^{188}$ The panel followed a different avenue this time when discussing the legal value of adopted GATT reports. In the panel's view, decisions to adopt reports should come under Article XVI of the WTO Agreement. Such decisions are not binding on subsequent panels since, as Article XVI of the WTO Agreement itself provides, "the WTO shall be guided by the decisions, procedures and customary practices followed by the CONTRACTING PARTIES to GATT 1947." Consequently, the legal effect of adopted GATT reports is not to bind subsequent panels dealing with the same issue, but simply to provide "guidance." On appeal, the AB followed some convoluted reasoning to end up in the same place:

We recognize that, as "decisions" within the meaning of Article XVI:1 of the WTO Agreement, the adopted panel reports in the Tax Legislation Cases, together with the 1981 Council action, could provide "guidance" to the WTO. The United States believes that the "guidance" to be drawn from the 1981 Council action, through footnote 59, is that the FSC measure is not an "export subsidy". The present dispute involves the interpretation and application of Article 3.1 (a) of the SCM Agreement and the question of whether the FSC measure involves export subsidies under that provision. In contrast, the 1981 Council action addresses the interpretation and application of Article XVI:4 of the GATT 1947. The "guidance" that the 1981 Council action might provide, therefore, depends, in part, on the relationship between these different provisions.

As a result, it is now settled that adopted GATT panel reports can provide useful guidance to subsequent WTO panels dealing with the same issue and that, in practice, recourse to them can been made in order to confirm an interpretation reached through other elements of the VCLT. ${ }^{189}$ A representative instance is Korea-Commercial Vessels, ${ }^{190}$ where the panel used the findings of a GATT panel to grasp the meaning of the term serious prejudice appearing in the SCM Agreement.

By contrast, unadopted GATT panel reports have, in principle, no legal status since they cannot come under the ambit of Article XVI of the WTO Agreement. The panel in JapanAlcoholic Beverages $I I^{191}$ held that unadopted reports "have no legal status in either the GATT

${ }^{188}$ Panel Report, United States-Tax Treatment for "Foreign Sales Corporations," W T/DS108/R (adopted Mar. 20, 2000); Appellate Body Report, United States_-Tax Treatment for "Foreign Sales Corporations," para. 115, W T/DS108/AB/R (adopted Mar. 20, 2000) (reported by Stanley L. Langbein at 94 AJIL 546 (2000)).

${ }^{189}$ Jackson, looking into the case law of the prior forty years, concludes that GATT panel reports have persuasive power over subsequent panels dealing with the same issue. JOHN H. JACKSON, THE WORLD TRADING SYSTEM: LAW AND POLICY OF INTERNATIONAL ECONOMIC RELATIONS (1989). Jackson's description is probably the closest we can get to an accurate picture of their legal status: their impact is not guaranteed since there is nothing like stare decisis in the GATT/W TO legal order; it depends on whether the subsequent panel is persuaded by the reasoning included in the prior panel's findings.

${ }^{190}$ Panel Report, Korea-Measures Affecting Trade in Commercial Vessels, paras. 7.591-.602, W T/DS273/R (adopted Apr. 11, 2005).

${ }^{191}$ Panel Report, Japan-Alcoholic Beverages II, supra note 148, para. 6.10; Appellate Body Report, JapanAlcoholic Beverages II, supra note 148, at 16. 
or the WTO system since they have not been endorsed through decisions by the Contracting Parties to GATT or WTO Members." Nevertheless, practice shows that WTO panels will still take them into account, assuming that their legal reasoning is persuasive, as the $\mathrm{AB}$ noted in Japan-Alcoholic Beverages II: "a panel could nevertheless find useful guidance in the reasoning of an un-adopted panel report that it considered to be relevant." In this same vein, the panel in U.S. - Lamb ${ }^{192}$ looked at both adopted and unadopted GATT reports to support one of its findings. Likewise, the panel in EC-Pipe Fittings ${ }^{193}$ cited an unadopted GATT report to support its legal conclusion on a particular issue.

WTO panel and AB reports. As a formal matter, WTO panel and AB reports, like GATT panel reports before, bind only the parties to the particular dispute and do not create binding precedent. Even so, since the $\mathrm{AB}$ is limited to a review of legal issues only, on many occasions its pronouncements are wider than transaction specific. Assuming for example, that the $A B$ is called to pronounce on the criteria that define likeness of goods under GATT Article III:2, its decision on this score will be valid for all similar transactions. Indeed, assuming the absence of distinguishing factors, the WTO membership will legitimately expect a repetition of the prior case law. Moreover, adjudicating bodies have an incentive to be coherent (absent distinguishing factors across cases, of course) since internal coherence of their case law is a contributing factor to their legitimacy. In so single case (except, of course, for the first) have WTO adjudicating bodies omitted references to prior WTO case law, even if that case law ran contrary to their conclusions.

In Japan-Alcoholic Beverages $I I^{194}$ the AB explicitly acknowledged that case law is transaction-specific; it nevertheless noted that an equivalent provision in the ICJ Statute did not prevent the ICJ from establishing its own jurisprudence:

It is worth noting that the Statute of the International Court of Justice has an explicit provision, Article 59, to the same effect. This has not inhibited the development by that Court (and its predecessor) of a body of case law in which considerable reliance on the value of previous decisions is readily discernible.

In U.S.-Shrimp (Article 21.5-Malaysia), ${ }^{195}$ the AB clarified the legal relevance of WTO panel and $A B$ reports. In its view, the rationale for treating adopted GATT reports as part of the GATT acquis also applied to WTO panel and AB reports:

This reasoning applies to adopted $\mathrm{AB}$ Reports as well. Thus, in taking into account the reasoning in an adopted $\mathrm{AB}$ Report - a Report, moreover, that was directly relevant to the Panel's disposition of the issues before it - the Panel did not err. The Panel was correct in using our findings as a tool for its own reasoning. Further, we see no indication that, in

192 Panel Report, United States—Safeguard Measures on Imports of Fresh, Chilled or Frozen Lamb Meat from New Zealand and Australia, para. 7.78, W T/DS177/R, W T/DS178/R (adopted May 16, 2001), modified by Appellate Body Report, United States-Safeguard Measures on Imports of Fresh, Chilled or Frozen Lamb Meat from New Zealand and Australia, WT/DS177/AB/R, WT/DS178/AB/R (adopted May 16, 2001).

${ }^{193}$ Panel Report, EC-Pipe Fittings, supra note 51, para. 7.280.

${ }^{194}$ Japan-Alcoholic Beverages III, supra note 148, at 13 n.30.

${ }^{195}$ Appellate Body Report, United States-Import Prohibition of Certain Shrimp and Shrimp Products, Recourse by Article 21.5 of the DSU by Malaysia, para. 109, W T/DS58/AB/RW (adopted Nov. 21, 2001) (reported by Louise de La Fayette at 96 AJIL 685 (2002)) [hereinafter U.S.—Shrimp (Article 21.5-Malaysia)]. 
doing so, the Panel limited itself merely to examining the new measure from the perspective of the recommendations and rulings of the DSB.

It seems that by the term acquis, the $\mathrm{AB}$ aims to capture the legitimate expectations by WTO members to see prior case law applied in future adjudicating experience, if relevant (that is, absent distinguishing factors across cases). This point was further clarified in U.S. - Line Pipe ${ }^{196}$ where the AB had the opportunity to explain that it will resort to its prior case law when, in the absent of other distinguishing features, the former and instant cases present factual similarities. Yet another illustration is EC-Sardines, ${ }^{197}$ where the AB included extensive references to prior case law in order to support its position that it has the legal authority to accept amicus curiae briefs.

A survey of the case law reveals instances in which panels dealing with the same issue have reached inconsistent conclusions. ${ }^{198}$ Since the majority of those reports are being appealed, however, many of these divergences may be eliminated. By contrast, when the AB actually has ruled on a particular issue, panels have rarely deviated. One such instance is Argentina-Preserved Peaches, ${ }^{199}$ where the panel voiced its disagreement with one of the AB's holdings. In the overwhelming majority of the cases, however, panels start their interpretative exercises through references to the $\mathrm{AB}$ case law. Although legally not bound to do so, panels will follow the $\mathrm{AB}$ either because they are genuinely persuaded by the reasoning or because they are aware that in case of deviation, there is little chance of eventually overturning prior case law. ${ }^{200}$ The panel report in India-Patents (EC) ${ }^{201}$ eloquently captures this point:

$[\mathrm{P}]$ anels are not bound by previous decisions of panels or the Appellate Body even if the subject-matter is the same ... . However, ... we will take into account the conclusions and reasoning in the Panel and Appellate Body reports in WT/DS50. Moreover, in our examination we believe that we should give significant weight to both Article 3.2 of the DSU, which stresses the role of the WTO dispute settlement system in providing security and predictability to the multilateral trading system, and to the need to avoid inconsistent rulings (which concern has been referred to by both parties). In our view, these considerations form the basis of the requirement of the referral to the "original panel" wherever possible under Article 10.4 of the DSU.

${ }^{196}$ Appellate Body Report, United States—Definitive Safeguard Measures on Imports of Circular Welded Carbon Quality Line Pipe from Korea, para. 102, WT/DS202/AB/R (adopted Mar. 8, 2002).

197 Appellate Body Report, EC-Sardines, supra note 112, paras. 155-62.

${ }^{198}$ For one such example, see the panel reports in EC-Countervailing Measures on Dynamic Random Access Memory Chips from Korea, W T/DS299/R (adopted Aug. 3, 2005), and United States-Countervailing Duty Investigation on Dynamic Random Access Memory Semiconductors (DRAMS) from Korea, W T/DS296/R (adopted July 20, 2005). The EC and United States countervailed Korea's alleged subsidization of Korean companies. Korea complained against both measures, presented identical claims and arguments to the two panels, but lost in one case (versus the $\mathrm{EC}$ ) and lost in the other (versus the United States).

${ }^{199}$ Panel Report, Argentina-Definitive Safeguard Measure on Imports of Preserved Peaches, para. 7.24, W T/DS238/R (adopted Apr. 15, 2003). More recently, a couple of panels dealing with the practice of zeroing (where, an investigating authority will not compute in the calculation of dumping margin transactions where no dumping has been found) have explicitly stated their disagreements with the AB's condemnation of the practice. See, for example, the panel report in United States-Measures Relating to Zeroing and Sunset Reviews, W T/DS322/R (adopted Jan. 23, 2007), and its findings at pages 138-77, 182-90, and 192-94.

${ }^{200}$ Since the losing party might have the incentive to appeal and to request from the AB that it reverse the panel's findings, thereby reaffirming its own case law.

${ }^{201}$ Panel Report, India_Patent Protection for Pharmaceutical and Agricultural Chemical Products, para. 7.30, W T/DS79/R (adopted Sept. 22, 1998). 
On most occasions, the $\mathrm{AB}$ gives the impression that it takes its own case law quite seriously. In only a few cases has it neglected its relevant case law on an issue, ${ }^{202}$ and in no case has it clearly stated that it was deciding a revirement de jurisprudence (overruling prior case law). In the majority of the cases, the $\mathrm{AB}$ starts its analysis recalling its prior case law on an issue, although it often adds helpful, new twists in the process.

Ideally, WTO adjudicating bodies should always refer to their prior case law. This is not to say that they should always reach the same outcome. Consistency is not an unqualified value, since one can be consistently wrong. In the presence of distinguishing factors, or even better intellectual arguments, those adjudicating bodies should be encouraged to change their minds — provided that they have explained their reasons for doing so. ${ }^{203}$

Previous GATT agreements. During the Tokyo round, a series of agreements were signed (the so-called Tokyo round codes). Participation in those agreements was optional. Most of these agreements have been carried over into the Uruguay round; for example, the Uruguay round $\mathrm{AD}$ agreement, for example, succeeded the Tokyo round AD agreement. Importantly, however, those two agreements (as well as many others carried over from one round to the other) are not identical. At the Uruguay round, participation (with the exception of the "plurilateral agreements") was not optional; these agreements were considered part of the "single undertaking." Although content is not identical, many of the provisions appearing in Tokyo round agreements have been carried over as such in the corresponding Uruguay round agreements. Reference to the Tokyo round agreements has thus been deemed appropriate in order to confirm an interpretation already reached. ${ }^{204}$ The Tokyo round agreements have been consistently treated as supplementary means of interpretation. An illustration of this pattern can be seen in Argentina-Poultry Anti-dumping Duties, ${ }^{205}$ where the panel dealt with a dispute on the consistency of Argentina's measures with the AD Agreement. In order to confirm its interpretation of Article 2, the panel referred to the more explicit wording of the corresponding provision in the Tokyo round AD Agreement.

UN Resolutions. The arbitrator's report in U.S._FSC (Article 22.6-U.S. $)^{206}$ contains an explicit reference to the International Law Commission's report on state responsibility, although he did not specify what its legal value was. The report, adopted as a resolution of the UN General Assembly, was intended to express reflect customary international law.

\footnotetext{
202 One good example can be seen in United States-Countervailing Measures Concerning Certain Products from the European Communities, W T/DS212/AB/R (adopted Jan. 8, 2003), and the United States -Imposition of Countervailing Duties on Certain Hot-Rolled Lead and Bismuth Carbon Steel Products Originating in the United Kingdom, WT/DS138/AB/R (adopted June 7, 2000). As Grossman and Mavroidis explain, the AB reached the second time it dealt with the same issue (does the price paid matter when previously subsidized operations are being auctioned off?) the opposite conclusion than the first time. The first time it ruled that a market price paid at auction always extinguishes the benefits previously received, and the second that it is not necessarily the case. Remarkably the subsequent report cites the previous one to support its conclusions. Gene M. Grossman \& Petros C. Mavroidis, Recurring Misunderstanding of Non-recurring Subsidies, in THE WTO CASE-LAW OF 2002, at 78 (Henrik Horn \& Petros C. Mavroidis eds., 2004).

${ }^{203}$ On this score, see POSNER, supra note 21.

${ }^{204}$ As noted above, however, the W TO adjudicating body in question made no explicit reference to VCLT Article 32 .

205 Panel Report, Argentina-Poultry Anti-dumping Duties, supra note 52, para. 7.358.

${ }^{206}$ Arbitration Report, United States-Tax Treatment for “Foreign Sales Corporations," Recourse to Arbitration by the United States under Article 22.6 of the DSU and Article 4.11 of the SCM Agreement, W T/DS108/ARB (adopted Aug. 30, 2002).
} 
OECD guidelines. The panel report in Mexico-Telecoms ${ }^{207}$ relied on the OECD guidelines to confirm its understanding of the term "anti-competitive practice." In doing so, the AB treated the OECD guidelines as supplementary means of interpretation.

Decisions by international courts. Occasionally, panels and the AB refer to decisions by other courts as means of supporting their own decisions. An appropriate illustration is India-Patents (U.S.), ${ }^{208}$ where the $\mathrm{AB}$ referred to the jurisprudence of the Permanent Court of International Justice (PCIJ) to support its finding that the determination of domestic law should be treated as a factual matter. In doing so, the AB did not clarify the legal status of such PCIJ jurisprudence. Nevertheless, it was arguably treating the PCIJ case law as supplementary means of interpretation.

Domestic law and practice. Pursuant to the VCLT (Article 27), domestic law cannot trump WTO law (a point explicitly acknowledged in the panel report in Argentina-Poultry Antidumping Duties). ${ }^{209}$ This does not mean, however, that domestic law cannot provide a source of inspiration for WTO law, especially as a gap-filling exercise: in EC-Tariff Preferences ${ }^{210}$ the panel examined domestic codes of conduct for attorneys-at-law-such as the objectivity and independence of legal counsel's professional, the right to consent to joint representation by the same counsel, and the equal right to discontinue such joint representation when conflicts potentially arise - on the way to deciding that such common features of professional ethical codes are equally appropriate in analyzing representational conflict of interest in within the WTO dispute settlement system. The panel, in this context, examined the Codes of Conduct of the American Bar Association, some U.S. states, Canada, the European Union, and some EU member states.

Doctrine. Sporadic references can be found in panel reports to the teachings and writings of highly qualified publicists in GATT law, but these references in the early WTO years were rare. The quantity of references has picked up over the years, usually in a self-serving mood (that is, to support interpretations reached). Doctrine has always been used as supplementary means of interpretation. ${ }^{211}$

\section{Other Interpretative Elements}

There are interpretative elements that panels have used but have failed to classify formally. Although it seems that such elements were used as supplementary means of interpretation, their formal absence of classification requires that we classify them under "Other." Most notably, WTO adjudicating bodies have used international treaties to interpret terms of the WTO Agreement and its annexes. In its original and its compliance reports in U.S.-Shrimp, ${ }^{212}$ the

${ }^{207}$ Panel Report, Mexico-Telecoms, supra note 32, para. 7.236.

${ }^{208}$ Appellate Body Report, India-Patent Protection for Pharmaceutical and Agricultural Chemical Products, para. 65, WT/DS50/AB/R (adopted Jan. 16, 1998).

${ }^{209}$ Panel Report, Argentina-Poultry Anti-dumping Duties, supra note 52, para. 7.108.

${ }^{210}$ Panel Report, EC-Conditions for the Granting of Tariff Preferences to Developing Countries, para. 7.11, W T/DS246/R (adopted Apr. 20, 2004), modified by Appellate Body Report, EC-Conditions for the Granting of Tariff Preferences to Developing Countries, W T/DS/246/AB/R (adopted Apr. 20, 2004).

${ }^{211}$ In U.S.-Shrimp, supra note 116, para. 114, for example, the AB cited Ian Sinclair in support of its position that recourse to VCLT Article 32 was warranted in order to confirm a conclusion is sought or to determine the meaning of a provision that remains uncertain after exhausting all references included in VCLT Article 31.

${ }^{212}$ Id.; Appellate Body Report, U.S.—Shrimp (Article 21.5-Malaysia), supra note 195. 
$\mathrm{AB}$ referred to various regional and multilateral environmental agreements (MEAs). The AB's invocation of such agreements in its original judgment led to a further dispute between the parties, and in the compliance ruling, the $\mathrm{AB}$ clarified the normative significance that it attached to such agreements in resolving the dispute between the parties: in its view, international agreements such as MEAs may not only be used as legal interpretation, but help to establish a wide agreement on certain facts (such as whether a species in endangered or whether certain resources are exhaustible), where such facts are pertinent to the application of a given legal provision, in this case GATT Article XX (g) (conservation of exhaustible natural resources). As the $\mathrm{AB}$ itself explained in U.S. - Shrimp (Article 21.5-Malaysia), ${ }^{213}$ the agreement is not thereby converted into an autonomous legal standard but is merely evidence of noncomparable — and possibly discriminatory-treatment of nonsignatories:

124. As we stated in United States - Shrimp, "the protection and conservation of highly migratory species of sea turtles ... demands concerted and cooperative efforts on the part of the many countries whose waters are traversed in the course of recurrent sea turtle migrations". Further, the "need for, and the appropriateness of, such efforts have been recognized in the WTO itself as well as in a significant number of other international instruments and declarations". For example, Principle 12 of the Rio Declaration on Environment and Development states, in part, that "[e]nvironmental measures addressing transboundary or global environmental problems should, as far as possible, be based on international consensus". Clearly, and "as far as possible", a multilateral approach is strongly preferred. Yet it is one thing to prefer a multilateral approach in the application of a measure that is provisionally justified under one of the subparagraphs of Article XX of the GATT 1994; it is another to require the conclusion of a multilateral agreement as a condition of avoiding "arbitrary or unjustifiable discrimination" under the chapeau of Article XX. We see, in this case, no such requirement.

130. At no time in United States - Shrimp did we refer to the Inter-American Convention as a "benchmark". The Panel might have chosen another and better word-perhaps, as suggested by Malaysia, "example". Yet it seems to us that the Panel did all that it should have done with respect to the Inter-American Convention, and did so consistently with our approach in United States_Shrimp. The Panel compared the efforts of the United States to negotiate the Inter-American Convention with one group of exporting WTO Members with the efforts made by the United States to negotiate a similar agreement with another group of exporting WTO Members. The Panel rightly used the Inter-American Convention as a factual reference in this exercise of comparison. It was all the more relevant to do so given that the Inter-American Convention was the only international agreement that the Panel could have used in such a comparison. As we read the Panel Report, it is clear to us that the Panel attached a relative value to the Inter-American Convention in making this comparison, but did not view the Inter-American Convention in any way as an absolute standard. Thus, we disagree with Malaysia's submission that the Panel raised the InterAmerican Convention to the rank of a "legal standard". The mere use by the Panel of the Inter-American Convention as a basis for a comparison did not transform the Inter-American Convention into a "legal standard". Furthermore, although the Panel could have chosen a more appropriate word than "benchmark" to express its views, Malaysia is mistaken

${ }^{213}$ Appellate Body Report, U.S.-Shrimp (Article 21.5-Malaysia), supra note 195, paras. 124, 130. 
in equating the mere use of the word "benchmark", as it was used by the Panel, with the establishment of a legal standard.

The $\mathrm{AB}$ report in EC-Asbestos ${ }^{214}$ contains references to World Health Organization conventions. Here, as in U.S. - Shrimp cited above, the AB appears to have used these instruments as evidence of a wide agreement on a factual state of affairs - the toxicity of asbestos and its seriousness as a public health challenge.

\section{CONCLUDING REMARKS}

\section{The Background}

It is for the WTO members to draw the list of sources of law. The mandate that the members gave to the WTO judge was to interpret the WTO contract, without undoing the agreed balance of rights and obligations (DSU Article 3.2). The legislative guidance (DSU Article 3.2) to have recourse to customary rules of interpretation, when interpreting the WTO contract, has been understood by the WTO judge as an implicit reference to the VCLT. Nothing shocking here, since the VCLT was, in this respect, codification of customary law. The judge is thus an agent with a mandate to use VCLT in a manner that does not undo the will of principals.

The questions arises whether the VCLT is a complete contract. The answer has to be negative for at least two reasons: first, the VCLT does not explicitly refer to the precise weight that should be given to each one of its interpretative elements, ${ }^{215}$ and second, the boundaries among the various elements mentioned in the VCLT are not always clear-cut, with the consequence that the classification exercise itself will affect outcomes. ${ }^{216}$ This latter point is especially important in the context of this article: due to the incompleteness of the VCLT, the WTO judge has some discretion in classifying the various interpretative elements; their legal significance will depend on the outcome of the classification exercise. Moreover, as we saw earlier, the WTO judge had to look outside the VCLT to decide, for example, on how to allocate the burden of proof.

\section{The Practice}

Against this background, the survey of WTO practice leads us to conclude:

- The WTO judge uses the VCLT in a compartmentalized manner: the conclusion about the interpretation of a certain term will, in the overwhelming majority of the cases, be reached when examining the ordinary meaning of the terms and will merely be confirmed through recourse to other VCLT elements.

- The direct consequence of this approach is twofold: first, there will be no need to look actively for contextual elements, or supplementary means, since the conclusion has been already reached, and all interpretative elements will merely support a fait

\footnotetext{
${ }^{214}$ Appellate Body Report, EC-Asbestos, supra note 115, paras. 114, 135.

${ }^{215}$ Recall the central argument of the present article that context should be the dominant element. We will return to it shortly.

${ }^{216}$ Recall our discussion concerning the boundaries between supplementary means and context: the list provides only two examples, with the consequence that the former category is indeterminate, and numerous elements could just as easily fall under one category or the other-albeit with extremely different legal consequences.
} 
accompli; and second, the WTO agent has classified, when in doubt, sources under supplementary means of interpretation and thus reduced their legal significance. A by-product of this approach is that we see fewer elements used.

- The WTO judge has failed to provide the rationale for its manner of treating secondary law.

\section{A Critique}

The title of VCLT Article 31 is "General Rule of Interpretation." Presumably, the legislator chose singular over plural (rule, not rules) for a good reason, and that reason must be that the various elements are part of a whole. It is those elements together that will provide the words in a treaty with their (intended) meaning. Words are, almost by definition, contextual, and their meanings vary accordingly. WTO adjudicating bodies have acknowledged as much by, on occasion, giving a different meaning to the same term: the term like (products) in GATT Article III: 4 was accorded a wider coverage than the term like (products) in GATT Article III:2. In the majority of cases, however, the adjudicating bodies have refused to consider that the meaning of treaty terms may differ with the context. Indeed, it is the context that defines the meaning of the terms used, and WTO adjudicating bodies should first ask the question "Why has a particular instrument become a WTO commitment?" before asking what that the particular details of that commitment are. The $\mathrm{AB}$, as briefly discussed above, has recently attempted to contain textualism (versus contextualism), arguing that recourse to dictionaries should be the first, and not the last, step. Empirically speaking, this declaration is one that has hardly been followed in practice. Some illustrations are appropriate here. In EC-TariffPreferences, ${ }^{217}$ the $\mathrm{AB}$ paid disproportionate attention to words indicating that the set of developing countries could be divided into subsets, each to enjoy larger or narrower preferences. Based on this understanding, the $\mathrm{AB}$ found in favor of the $\mathrm{EC}$ approach of conditioning benefits upon the satisfaction of unilaterally defined criteria. ${ }^{218}$ It did not even ask the question whether distinguishing between various developing countries should be a multilateral exercise or simply a matter of individual preferences. Had it done that, the $\mathrm{AB}$ would have noticed that the context of the "Enabling Clause" 219 clearly supports multilaterally agreed, but not unilaterally imposed, distinctions, like the one already included between developing and least developed countries. In U.S. - Offset Act (Byrd Amendment), ${ }^{220}$ the $\mathrm{AB}$ condemned the U.S. practice because it goes against dumping (since it discourages dumping) and is not an antidumping duty. The whole judgment rests on its understanding of term against. What if Byrd payments incite more dumping, as Horn and Mavroidis ${ }^{221}$ show to be theoretically possible? Should not the $A B$, instead of spending time and effort to understand the many meanings of the term against, simply try to understand what was intended to be covered by the provision in question?

${ }^{217}$ Appellate Body Report, EC-Tariff Preferences, supra note 121.

${ }^{218}$ Recall that the AB condemned the EC practice only because the list appearing in its Generalized System of Preferences was closed. Had it been open, the AB would have admitted it, assuming that the $A B$ considered the selection criteria objective.

${ }^{219}$ Differential and More Favourable Treatment, Reciprocity and Fuller Participation of Developing Countries, Nov. 28, 1979, GATT B.I.S.D. (26th Supp.) at 203.

${ }^{220}$ Appellate Body Report, U.S._-Offset Act (Byrd Amendment), supra note 106.

${ }^{221}$ Henrik Horn \& Petros C. Mavroidis, United States-Continued Dumping and Subsidy Offset Act of 2000, in THE WTO CASE-LAW OF 2003, at 52 (Henrik Horn \& Petros C. Mavroidis eds., 2006). 
The term "so as to afford protection," which was included in GATT Article III, has been deprived of any substantive meaning as a result of an interpretative pattern that is oblivious to the very purpose of that article. As a result of this approach, in Chile-Alcoholic Beverages, ${ }^{222}$ for example, Chile was condemned for violating its obligations under GATT Article III because it had enacted a tax regime whereby the higher the alcoholic content of a drink, the more burdensome the taxation-notwithstanding the evidence that Chilean producers had been burdened the most by this very regime. ${ }^{223}$

WTO adjudicating bodies will do much better by simply dropping recourse to dictionaries and by starting to ask questions concerning the purpose of the contractual terms whose meaning they seek. Conclusions concerning the meaning of terms should come after exhaustion of all the elements of VCLT Article 31 and not after a superficial look at a dictionary or two.

What also matters - especially given the purposes of this article-is the external effect of textualism, and not textualism itself: by relying on the text and taking the view that words are decisive, panels and the AB have reduced the opportunity for extra-WTO law to inform the interpretation of the WTO contract. For the sake of argument, let us assume that such sources should be understood as supplementary means, as the AB itself prefers to see them, whenever it has recourse to such elements. Recourse to supplementary means is, as per VCLT Article 32, a matter of discretion - and therefore not a matter of obligation. But discretion can be used or abused, and absence of obligation should not be equated with carte blanche. Take U.S.Shrimp, ${ }^{224}$ for example: had the AB paid attention to the preparatory work of GATT Article $\mathrm{XX}(\mathrm{g})$, it would have detected that the transactions that negotiators had in mind related to nonliving resources only. ${ }^{25}$ The end result of the dispute might have been correct, and it was also a politically welcome outcome. But it is still puzzling how a term such as exhaustible natural

\footnotetext{
${ }^{222}$ Appellate Body Report, Chile-Taxes on Alcoholic Beverages, WT/DS87/AB/R, WT/DS110/AB/R (adopted Jan. 12, 2000).

${ }^{223}$ See the excellent analysis in Lothar Ehring, De Facto Discrimination in World Trade Law: National and Most Favoured Nation Treatment-or Equal Treatment, 36 J. WORLD TRADE 921 (2002). The affection for textualism is especially noticeable in the safeguards case law, where the $A B$ has based some of its conclusions on the very thinnest of distinctions: it held, for example, that unforeseen developments should be distinguished from unforeseeable developments, without explaining where the difference lies, and that significant injury is not insignificant injury, again without explaining what the two terms mean. See Alan O. Sykes, The Safeguards Mess: A Critique of WTO Jurisprudence, 2 WORLD TRADE REV. 261 (2003). This extreme textualism is not, however, confined to safeguards case law. As Trebilcock and Soloway show, the AB has distinguished science from nonscience in the SPS case-law without explaining what the distinguishing criteria are. Michael Trebilcock \& Julie Soloway, International Trade Policy and Domestic Food Safety Regulation: The Case for Substantial Deference by the WTO Dispute Settlement Body Under the SPS Agreement, in THE POLITICAL ECONOMY OF INTERNATIONAL TRADE LAW 537 (Daniel L. M. Kennedy
} \& James D. Southwick eds., 2002).

224 Supra note 116.

225 See, for example, UN Doc. E/PC/T/C.II/50 (Nov. 13, 1946) at pp. 5 ff, a document from the London Conference. There negotiators were discussing, inter alia, the ambit of Article 37 of the London Draft, which became GATT Article XX. The remarks of the Indian delegate (Ganguli), along with the reactions to them, lend support to the argument that negotiators saw GATT Article XX $(\mathrm{g})$ as protecting nonliving resources, whereas the protection of living organisms was the domain of GATT Article XX(b) (which, of course, is associated with a more stringent legal test for compliance). As Steve Charnovitz notes in Exploring the Environmental Exceptions in GATT Article XX, 25 J. WORLD TRADE 37 (1991), in parallel negotiation concerning an international commodity agreement (fisheries and wildlife), the same term, exhaustible natural resources, was used to cover both living and nonliving organisms. A remark by the chairman of the working group discussing the commodity agreement (WyndhamWhite) — to the effect that the term appearing in Article XX (g) GATT covered fisheries as well— does lend to confusion. Nevertheless, an examination of the history discloses that the term exhaustible natural resources covered nonliving resources only. For a start, the discussion about fisheries was within a different context-namely, that of a commodity agreement that would come under the ITO, not the GATT itself. Moreover, subsequent discussions 
resources, which is anything but self-interpreting, suddenly becomes so clear: the $A B$ invoked the "principle of evolutionary interpretation" to justify its choice-at best, an obscure principle of interpretation that has rarely been invoked in international adjudication-and then used it to counterbalance and overrule the will of negotiators! The AB's handling of the Modalities Paper ${ }^{226}$ provides yet another example. The document was clearly meant to be used in order to calculate the commitments made. The absence of a formal decision on it was both consonant with standard negotiating practice at the WTO and appropriate since the document was meant to be used in that particular negotiation (and it was, indeed, so used). Should not the $\mathrm{AB}$ have paid at least some attention to that document instead of dismissing its relevance altogether and trying to re-construct itself what might have been intended in a negotiation that occurred ten years before its judgment?

The unwillingness of WTO adjudicating bodies to look beyond the text is not confined to their mistreatment of some preparatory work; international treaties relating to the same subject matter have also been neglected. The most explicit pronouncement to this effect came in the recent panel report in EC-Biotech Products, ${ }^{227}$ where the panel refused to look into MEAs with broad participation, simply because they had not been signed by all WTO members. VCLT Article 30 makes it clear, however, that to the extent that the rights of other parties to a treaty are not affected, a court should look into treaties concluded between a subset of the original partners, provided that the subsequent and the original treaties deal with the same subject matter. Recall that it was the AB itself that, in its first-ever dispute, ${ }^{228}$ declared that it would interpret the WTO contract in accordance with the VCLT.

So far, for a number of reasons, the outcomes of WTO adjudications have not suffered much from this attitude of neglecting extra-WTO sources. The ever increasing importance of nontariff barriers (NTBs), however, suggests that this situation might change in the not too distant future. Moreover, reference to other legal sources might serve to increase the legitimacy of reports, especially on controversial issues. Let us assume, for example, that the AB had checked the preparatory work of GATT Article XX $(\mathrm{g})$ and had come to the conclusion (as it had in the actual case) that perverse results would ensue from adhering to outmoded attitudes and confining the term exhaustible natural resources to nonliving resources. In that situation, the $A B$ would be well-advised to look at CITES and use that agreement as supplementary means: 169 states now accept that all forms of sea turtles are endangered species. Instead, during the U.S. Shrimp litigation, the AB opted for some oblique references to CITES without clarifying the legal significance of this broad consensus. ${ }^{229}$ It is worth noting, too, that as a result of the ever increasing concern with environmental, public health, and related issues, there are many agreements in addition to CITES that could help WTO adjudicating bodies when dealing with issues of that character.

during the Havana Conference confirm that negotiators treated fisheries and wildlife as a special case. For this last point, see UN Docs. E.CONF.2/C.5/9, at 21(1947), and E.CONF.2/C.5/SR.7, at 2 (1947).

226 See supra note 170 and accompanying text.

227 Panel Report, EC-Measures Affecting the Approval and Marketing of Biotech Products, WT/DS291/R, WT/DS292/R, WT/DS293/R, corr.1 \& adds.1-9 (adopted Nov. 21, 2006) (reported by Simon Lester at 101 AJIL 453 (2007)).

${ }^{228}$ See Appellate Body Report, U.S.-Gasoline, supra note 111, and accompanying text.

${ }^{229}$ CITES could thus help the judge to reach a better view of the criteria for classifying a species as endangered or resources as exhaustible. And instead of guessing what should and not be so classified, the judge could cite-in support of his or her decision — a convention representing today's most sophisticated understanding of those terms. 
Recourse to extra-WTO sources might well be required in order to fill some inescapable gaps. Recall that, absent recourse to the principle actori incumbit probatio, the $\mathrm{AB}$ would have had a hard time to explain how the burden of proof is allocated under WTO law. But the need for gap filling will continue to arise; the need to allocate the burden of proof was not unique. It must be cautioned, however, that the use of extra-WTO sources ${ }^{230}$ should satisfy the strict test established in Trachtman: ${ }^{231}$ as a matter of interpreting WTO law and not, for example, as means of circumventing the (occasional) absence of will by the MEA partners to establish a forum for adjudicating their MEA-related disputes.

Finally, the treatment of secondary law by WTO adjudicating bodies leaves much to be desired. Barfield ${ }^{232}$ has criticized the imbalance between the legislative and the adjudicative function in the WTO. It is true that, as things stand, the majority of the legislative output is confined to the renegotiation of agreements; new agreements emerge only when a trade round has been successfully concluded. This is not to suggest that there is no activity in between rounds. As is clear from our previous discussion of the TRIPS amendment, ${ }^{233}$ such activity can be quite formal. Practice indicates a willingness to look into some secondary law-but no explicit discussion of its status. Implicitly, the $A B$ seems to accept that form matters, since it is an appropriate proxy for legislative intent. This makes sense, and the AB should go ahead and be explicit about it. At the same time, it will find it worth looking at the various decisions/recommendations that other, hierarchically lower WTO organs adopt, and use them as interpretative elements (supplementary means) of the WTO sources of law. The ADP Committee recommendations on the length of $\mathrm{POI}^{234}$ are an excellent example of how these elements may be put to good use.

\section{No (Major) Change Required}

All of the suggestions made above can take place using the tools already included in the VCLT. ${ }^{235}$ WTO adjudicating bodies would thus be required to honor-no more, and no less-their pronouncements to the effect that they will observe the VCLT. What remains to be seen, however, is whether the current system of using ad hoc panelists can rise to the task as outlined above. It is probably unrealistic to request from trade delegates (the typical panelists) to suddenly change their perspective and to move outside the (illusory) comfort of the

\footnotetext{
${ }^{230}$ Recall that in EC_Chicken Cuts, supra note 133, the AB held that the HS treaty is part of the WTO's context. So far, nothing else has been so classified in WTO case law, but it remains unclear why even the HS treaty should be considered context. The AB states in paragraph 197 of its report that the HS treaty is context, in paragraph 198 that it is context because the Agreement on Agriculture refers to it (without explaining what to make of the absence of any reference to the HS treaty in the GATT, which regulates all nonagricultural products), and in paragraph 199 that it is context because of broad consensus among W TO members to use it when scheduling. Absent further information on the rationale for treating a legal document as context, we simply cannot predict what else could be so understood.

231 See supra note 21.

${ }^{232}$ Claude Barfield, Free Trade, Sovereignty, Democracy: The Future of THe World Trade ORGANIZATION (2001).

233 See supra note 39 and accompanying text.

234 See supra text accompanying notes 47-55.

235 There is consequently no need even to enter the (ongoing) discussion on fragmentation of public international law.
} 
covered agreements in order to adjudicate disputes. ${ }^{236}$ Reasoning backward from this point, the current design of panels is probably the main reason why trading nations generally abstain from submitting claims that would demand that panels step outside the four corners of the covered agreements. The changing needs of WTO adjudication thus present, in this context, yet another argument to professionalize the paneling of W'TO disputes.

236 The influence of the WTO secretariat, the only inflexible element in panel formation, is difficult to ascertain. There are reasons to believe, however, that it accepts the current state of affairs. See Håkan Nordström, The World Trade Organization Secretariat in a Changing World, 39 J. WORLD TRADE 819 (2005). 